\title{
Review
}

\section{Radiolaria: achievements and unresolved issues: taxonomy and cytology}

\author{
Noritoshi SUZUKI ${ }^{1} * *$ Yoshiaki Aita ${ }^{2}$ \\ ${ }^{1}$ Institute of Geology and Paleontology, Graduate School of Science, Tohoku University, Sendai 980-8578, Japan \\ ${ }^{2}$ Department of Geology, Faculty of Agriculture, Utsunomiya University, Utsunomiya 321-8505, Japan
}

Received 18 November 2008; Accepted 14 December 2010

\begin{abstract}
The essentials of the taxonomy and cytology of Radiolaria at the order level are summarized from approximately 110 papers. Living Radiolaria comprise representatives of the following orders: Acantharia, Collodaria, Spumellaria, cyrtid Nassellaria, spyrid Nassellaria and Taxopodia (=Sticholonche). This analysis is based on the most recent molecular biological and fossil data. Phaeodaria, which used to belong to the Radiolaria, belong to the Cercozoa now. Heliozoa are closer to the Cercozoa than to the Alveolata or Radiolaria. A molecular phylogenetic analysis indicates that Polycystina (including Collodaria, Spumellaria and Nassellaria) should not be treated as a monophyletic group.

"Polycystine" Radiolaria are characterized by the presence of axopodia, a capsular wall, and a fusule. The endoplasm consists of the Golgi bodies, mitochondria, and other organelles, whereas the ectoplasm is an alveolated reticulum with food, digestive, and perialgal vacuoles, suggesting zonal specialization. The Acantharia are characterized by the presence of a periplasmic cortex with myoneme, acting as a motile contractile plasmalemma, rather than a capsular wall. Taxopodia have thick axopodia and a thick nuclear wall instead of a capsular wall. Characteristic protoplasmic structures such as an intracapsular axopodial system and nucleus are found in "polycystine" Radiolaria, but these structures do not seem to reflect phylogenetic relationships.
\end{abstract}

Key words: Acantharia, Phaeodaria, polycystine, Radiolaria, Taxopodia

\section{Introduction}

Radiolarians are planktonic unicellular Protoctista with a symmetrical or asymmetrical skeleton such as in a spherical, discoidal, or conical shape. Their skeleton size ranges from 40 to $400 \mu \mathrm{m}$, and colonial Radiolaria form gelatin packs a few meters in length. Radiolarians appeared early in the Cambrian (ca. 530 million years ago) and inhabit shallow-to-open oceans at depths of up to $4,000 \mathrm{~m}$ in the modern ocean. Although no typical freshwater members of the Radiolaria have been found, at least 2,500 genera/subgenera and 15,000 species (living and fossil) have been reported since radiolarians were first recognized and described by Meyen (1834). Of these, approximately 800 1000 radiolarian species are currently recognized in the oceans (N Suzuki unpubl). Radiolaria are important fossils for determining geological age at a resolution of 1,000 10,000 years and for understanding oceanographic history. However, they have long been ignored because of discussions suggesting the relative unimportance of geology held

Corresponding author: Noritoshi Suzuki; E-mail, norinori@m.tohoku.ac.jp between 1940 and the 1950s (e.g. Kobayashi \& Kimura 1944). Substantive research on Radiolaria began again around the start of the Deep Sea Drilling Project (DSDP) in 1968. Since then, there have been 40 years of sustained international drilling effort (the International Program of Ocean Drilling [IPOD], the Ocean Drilling Program [ODP], and the Integrated Ocean Drilling Program [IODP]) to reveal Earth history as recorded below the sea floor (Integrated Ocean Drilling Program 2007). Prior to 1968, fewer than 900 papers were published worldwide on radiolarians; between 1968 and 2007, more than 4,000 papers have been published (Fig. 1).

Several books entitled Radiolaria were published after 1980 (Anderson 1983, Petrushevskaya 1986, De Wever et al. 2001, Afanasieva \& Amon 2006), and comprehensive books on protozoans (Boltovskoy 1999, Lee et al. 2000) summarized knowledge of Radiolaria, including Acantharia. Short reviews were also published in many languages (in English by Lazarus (2005), Japanese by Itaki (2005) and Suzuki \& Aita (2011), and French by De Wever et al. (1994)). However, with ongoing research, at least 1,000 radiolarian papers have been published in the past 


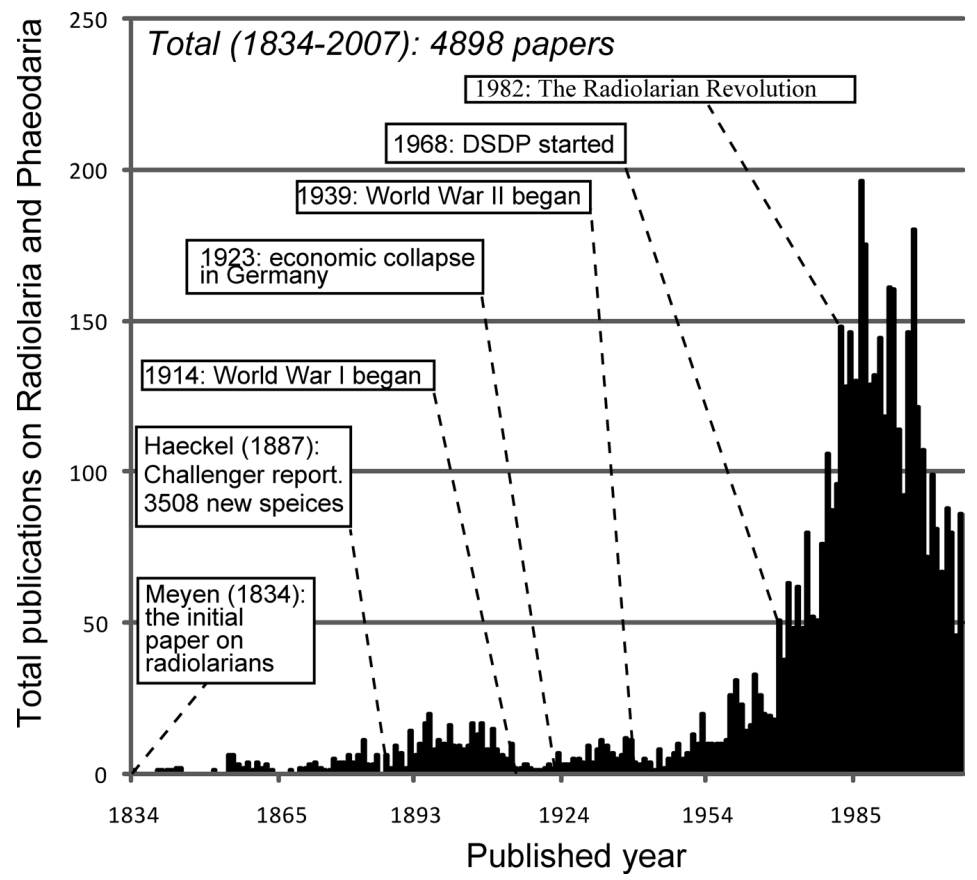

Fig. 1. Annual number of publications regarding Radiolaria from 1834 to 2007. Since Meyen (1834) first published two radiolarian new species, a total of 4898 publications regarding radiolarians (including Phaeodaria) have been published worldwide. Publications increased in number around the year 1968 when the Deep Sea Drilling Project, a scientific program to drill into the seafloor for studies on Earth Science, started. A significant increase in the number of publications occurred around 1982, the year of "The Radiolarian Revolution." The Radiolarian Revolution accompanied a paradigm shift in geology, when the central dogma in geology of the Geosyncline Theory was replaced the Plate Tectonics Theory with the occurrence of Mesozoic radiolarians in the Paleozoic Chichibu Geosyncline Belt in Japan. Data are from Network of Osaka Micropaleontologists (2007).

decade (1997-2007). This explosion of new knowledge has resulted in these reviews and textbooks becoming outdated. In particular, the concept of "Radiolaria" has been drastically revised in recent years, with increasing knowledge of taxonomic relationships based on molecular biological analyses (e.g. Kunitomo et al. 2006). Thus, almost all systematic treatments of "Radiolaria" published prior to 2006 are outdated.

The object of this review is to summarize the current understanding of Radiolaria for those who are interested in practical knowledge for reading radiolarian papers. First, we focus on radiolarian taxonomy and cytology. Morphological terminology mainly follows Petrushevskaya (1984a), Suzuki (1998, 2006), De Wever et al. (2001), and Ogane \& Suzuki (2006). As a field, radiolarian taxonomy is as yet so immature that specialists tend to avoid discussion at genus and family levels because they are strongly conscious of the hazardous interim application of genus names. Cytology is important in understanding radiolarians at the cellular level, as well as for understanding their life history, and physiology.

\section{Taxonomy}

The term "Radiolaria" (Müller 1858) initially referred to small organisms with a special membrane called a "capsu- lar wall" within an extra-nuclear protoplasm, as well as "axopodia", which are straight radiating pseudopodia with an axoneme bundle. The "capsular wall" in this group is a protoplasmic membrane that divides the extra-nuclear protoplasm into two specialized zonal portions. As commonly happens, definitions of "Radiolaria" are not necessarily the same from one publication to another because even radiolarian specialists have different conceptual understandings (Petrushevskaya 1981, Lee et al. 2000, De Wever et al. 2001, Pawlowski \& Burki 2009). The minimum required taxonomic names for understanding radiolarian papers are shown in Fig. 2. Radiolaria consist of Collodaria, Spumellaria, and Nassellaria which have a siliceous skeleton, and Acantharia with a strontium sulfate $\left(\mathrm{SrSO}_{4}\right)$ skeleton. Taxopodia are monospecific: Sticholonche zanclea Hertwig is the only species recognized. In addition, extinct Radiolaria include the orders Archaeospicularia (middle CambrianSilurian), Albaillellaria (Silurian-earliest Triassic), Entactinaria (Cambrian-Permian?), and Latentifistularia (Early Carboniferous-earliest Triassic) (De Wever et al. 2001).

We summarize reliable phylogenetic relationships between the radiolarian orders and Phaeodaria in Fig. 3. Acantharia were formerly treated as a class (e.g. Lee et al. 2000), but we tentatively demote it to the level of order to conform with the taxonomic ranks of the other radiolarian orders. We hereafter summarize herein the living Radiolaria 


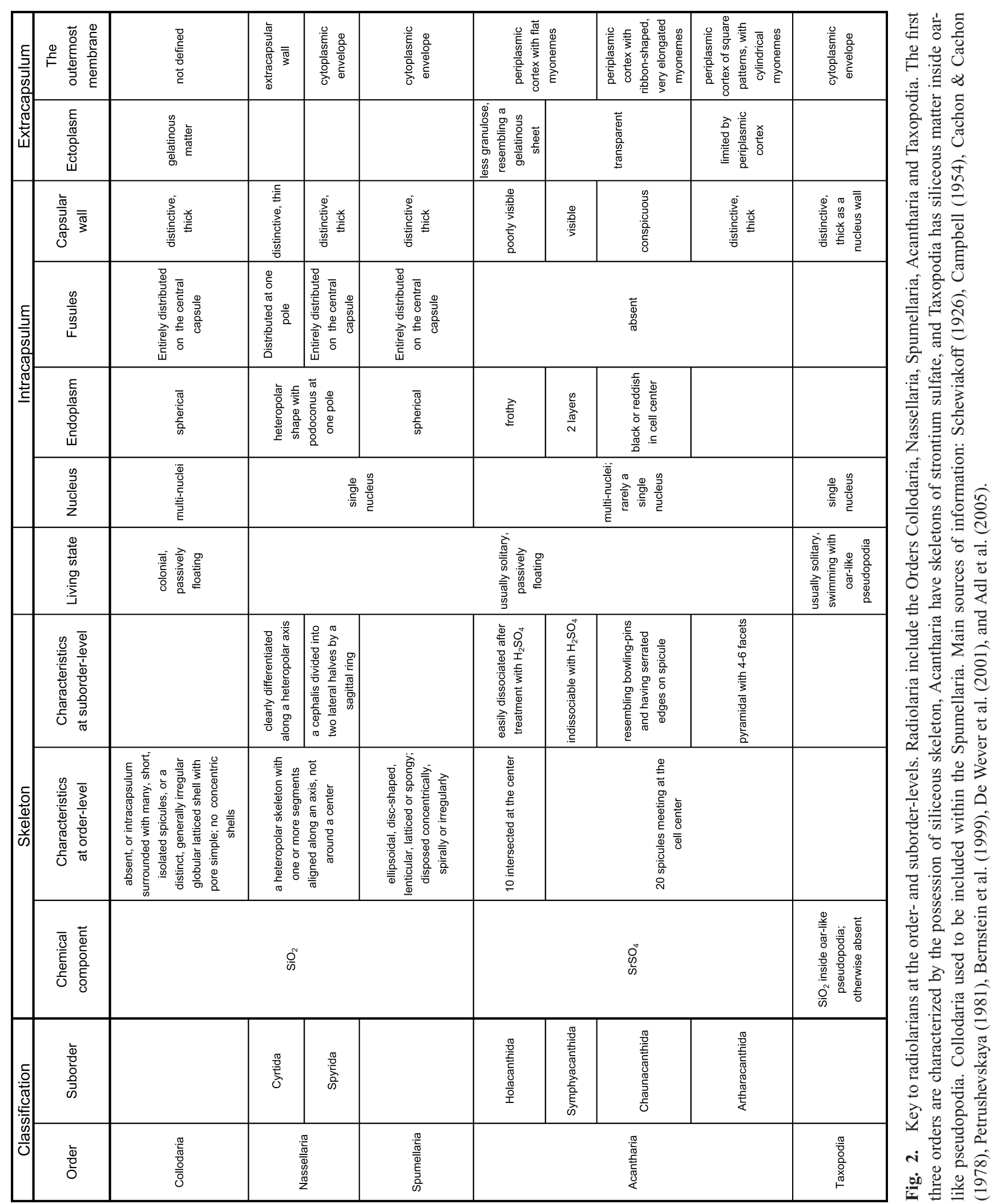



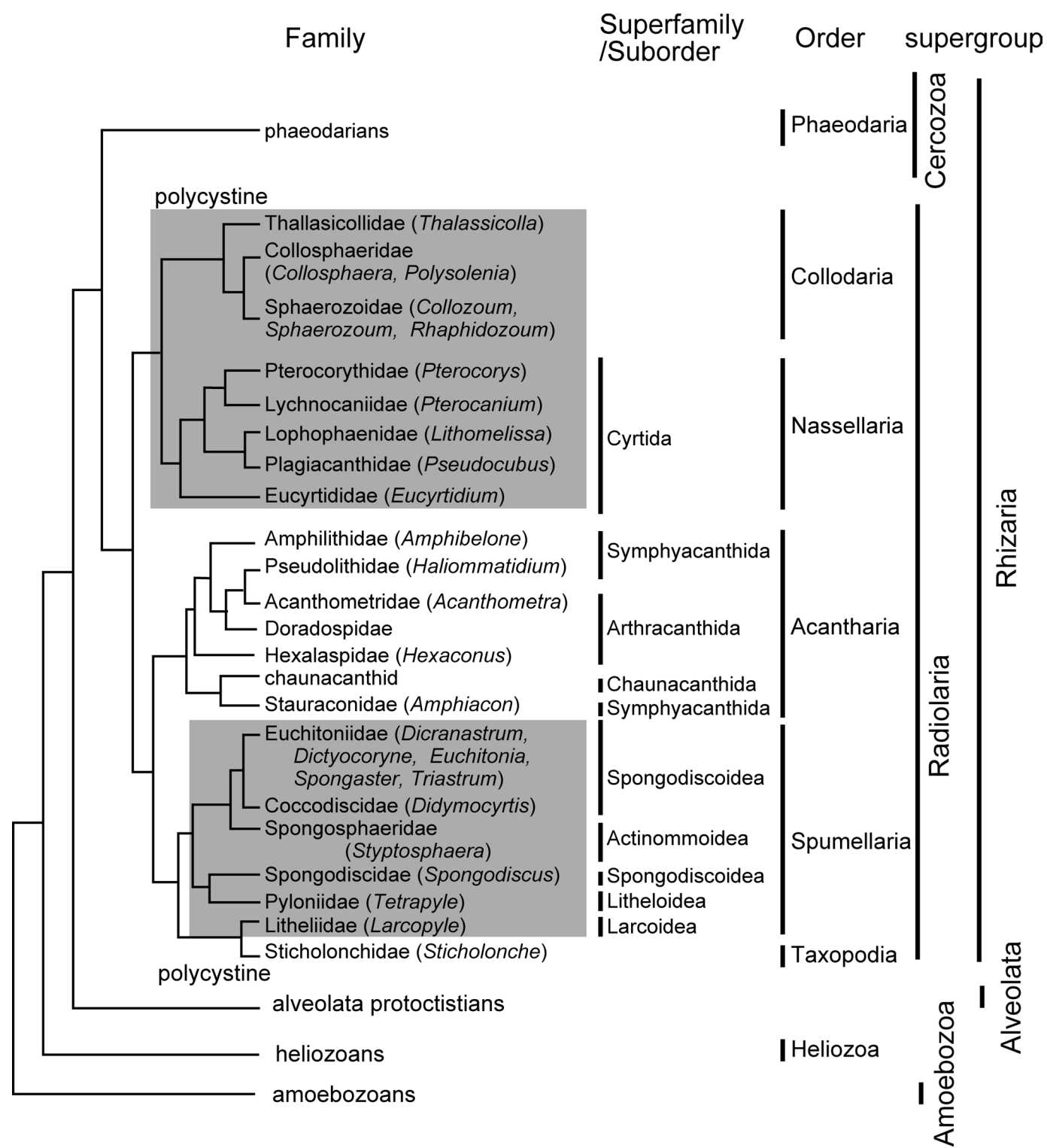

Fig. 3. Molecular phylogenetic relationships of the Radiolaria: Cercozoa, Alveolata, Heliozoa, and Amoebozoa (not to scale). Although Adl et al. (2005) regarded "Radiolaria" as a polyphyletic group, current knowledge on molecular phylogeny (CavalierSmith \& Chao 2003, Takahashi et al. 2004, Oka et al. 2005, Yuasa et al. 2005, 2006, Kunitomo et al. 2006) evidently shows that Radiolaria is a monophyletic group. Collodaria were previously considered to be a member of the Spumellaria (e.g. Adl et al. 2005), but recent data suggests instead that it is closely related to Nassellaria rather than Spumellaria. "Sticholonche" in Adl et al. (2005) has already been classified in the Order Taxopodia by Fol (1883). With respect to order- or suborder-level, there is no molecular phylogenetic data for the nassellarian Spyrida.

at the order level, and discuss current problems at the family through species levels. We eliminate the familiar taxonomic criterion "Polycystina" but retain the term to mean "diatom-like" for appellative purposes, such as in the form "polycystine" Radiolaria, referring to a radiolarian with a siliceous skeleton. Terminology for skeleton, protoplasm and pseudopodial systems are highly complex so that abbreviations concerning the skeleton and protoplasm are listed in Tables 1 and 2 and the brief definitions of pseudopodia are summarized in Table 3.

\section{Order Acantharia Haeckel (Fig. 4A-H)}

Acantharia possess a strontium sulfate $\left(\mathrm{SrSO}_{4}\right)$ skeleton that easily dissolves in seawater after death. Consequently, there are no reliable fossil records. Acantharia commonly make up a major part of the radiolarian biomass in seawater, exceeding $5.0 \times 10^{4}$ indiv. $\mathrm{m}^{-3}$ in the East China Sea (Tchang \& Tan 1964). The skeleton is marked by a very sophisticated symmetrical arrangement of 10 or 20 radial spicules named using Müller's rule (Fig. 4A). These radial spicules vary in size and form among species, but the prin- 
Table 1. Skeletal terminology and abbreviations in Radiolaria. Although more than 250 skeletal terms have been proposed and used to describe the morphology of Radiolaria, only 30 essential terms are summarized in this table.

\begin{tabular}{|c|c|c|c|c|c|}
\hline $\begin{array}{l}\text { Taxonomic } \\
\text { specification }\end{array}$ & Abbreviations & Terms & $\begin{array}{c}\text { Taxonomic } \\
\text { specification }\end{array}$ & Abbreviations & Terms \\
\hline \multirow[t]{5}{*}{ All Radiolaria } & & & Nassellaria & & \\
\hline & apr & aperture & & $\boldsymbol{A}$ & apical ray \\
\hline & sk & siliceous skeleton & & $a b$ & abdomen \\
\hline & $\mathrm{Sp}$ & spicule & & $\mathrm{Ah}$ & apical horn (=apical spine) \\
\hline & & & & $\operatorname{Arch} A V$ & arch connecting $\boldsymbol{A}$ and $\boldsymbol{V}$ \\
\hline \multirow[t]{6}{*}{ Acantharia } & & & & bf & basal feet \\
\hline & as & acantharian spicules & & ce & cephalis \\
\hline & e & equatorial spicule & & $D$ & dorsal ray \\
\hline & $\mathrm{p}$ & polar spicule & & $l$ & lateral rays to the dorsal (apical) side \\
\hline & $\mathrm{t}$ & tropical spicule & & $L$ & lateral rays to the ventral side \\
\hline & & & & $M B$ & median bar \\
\hline \multirow[t]{8}{*}{ Spumellaria } & & & & ps1 & first abdominal segment \\
\hline & by & by-spine & & ps2 & second post-abdominal segment \\
\hline & cs & cortical shell & & ps3 & third post-abdominal segment \\
\hline & dbs & double medullary shell & & th & thorax \\
\hline & ma & macrosphere & & $\boldsymbol{V}$ & ventral ray \\
\hline & $\mathrm{mi}$ & microsphere & & $\mathrm{Vh}$ & ventral horn $(=$ ventral spine $)$ \\
\hline & $\mathrm{rb}$ & radial beam & & & \\
\hline & rs & radial spine & & & \\
\hline
\end{tabular}

cipal arrangement is constant as follows: four equatorial spicules (red spicules in Fig. 4A) intersect at a $90^{\circ}$ angle on the equatorial plane; eight tropical spicules (green spicules in Fig. 4A) rise on both hemispheres at a $30^{\circ}$ degree angle from the equatorial plane and are twisted $45^{\circ}$ from the equatorial spicules in polar view; eight polar spicules (blue spicules in Fig. 4A) that rise on both hemispheres at a $60^{\circ}$ angle from the equatorial plane and that appear to overlap with the equatorial spicules in polar view. All spicules are always fused at the center of the cell, and are joined with protoplasmic strands called "spicular cement." Similar symmetrical arrangements of radial spicules/spines are common not only in Acantharia but also in Spumellaria, contributing to common misidentification between the orders (Fig. 4B). However, using Müller's law, it is easy to distinguish Acantharia (left in Fig. 4B) from Spumellaria (right in Fig. 4B). Radial spines of Spumellaria do not occur in a complete symmetric arrangement such as that described by Müller's law.

This oriented perspective of Acantharia is less important for identification at the suborder and lower taxonomic levels (Fig. 2). Acantharia comprise four suborders (as orders in Schewiakoff 1926, Campbell 1954, Reshetnyak 1981, Bernstein et al. 1999) on the basis of protoplasmic structure: Holacanthida (Fig. 4C), Symphyacanthida (Fig. 4D), Chaunacanthida (not figured), and Arthracanthida (Fig. 4B, E-H). However, the molecular analysis of acantharian species significantly contradicts Schewiakoff's (1926) higher classification (Fig. 3) (Oka et al. 2005), suggesting that a revision of this classification is necessary.

A total of 50 genera and 150 species are counted as valid taxa, according to the comprehensive work of Schewiakoff (1926) (Bernstein et al. 1999). This monograph is fundamental to all subsequent work on acantharian taxonomy (Campbell 1954, Reshetnyak 1981, Tan 1998, Bernstein et al. 1999, Febvre et al. 2000). Classification criteria used at the species level include protoplasmic color and structure and the detailed shape of each radial spicule, but full descriptions with images showing acantharian color are limited to only a few studies (Haeckel 1862, Schewiakoff 1926, Suzuki et al. 2009b). The taxonomic summary of the 126 acantharian species by Bernstein et al. (1999) is a very useful diagnostic guide and check-list. There are no fossil records.

\section{Order Spumellaria Ehrenberg (Figs. 4I-Q, 5A-B)}

Spumellaria are closely related to Acantharia, on the basis of molecular analysis (Fig. 3). The definition of Spumellaria is very simple: having concentric siliceous $\left(\mathrm{SiO}_{2}\right)$ skeletal structures (Fig. 4I-Q). Since Haeckel (1862, 1882, 1887) established a broad outline of the radiolarian taxonomic hierarchy on the basis of test symmetry, Spumellaria with a spherical siliceous skeleton have been traditionally classified into several superfamilies: Actinommoidea (Figs. 4I-L, 5A, B) with a concentric test structure, Litheloidea with a test containing spiral structures (Fig. 4P, Q), Pylonioidea possessing girdles in successive perpendicular planes (Fig. 4P, Q), and Spongodiscoidea with a diskshaped or flattened test (Fig. 4M, N). Their taxonomic ranks, however, vary from subsuperfamily to suborder among textbooks. 
Table 2. Cytological terminology and abbreviations in Radiolaria. Since no recent list of cytological terminology exists, we list here important cytological terms from more than 50 references.

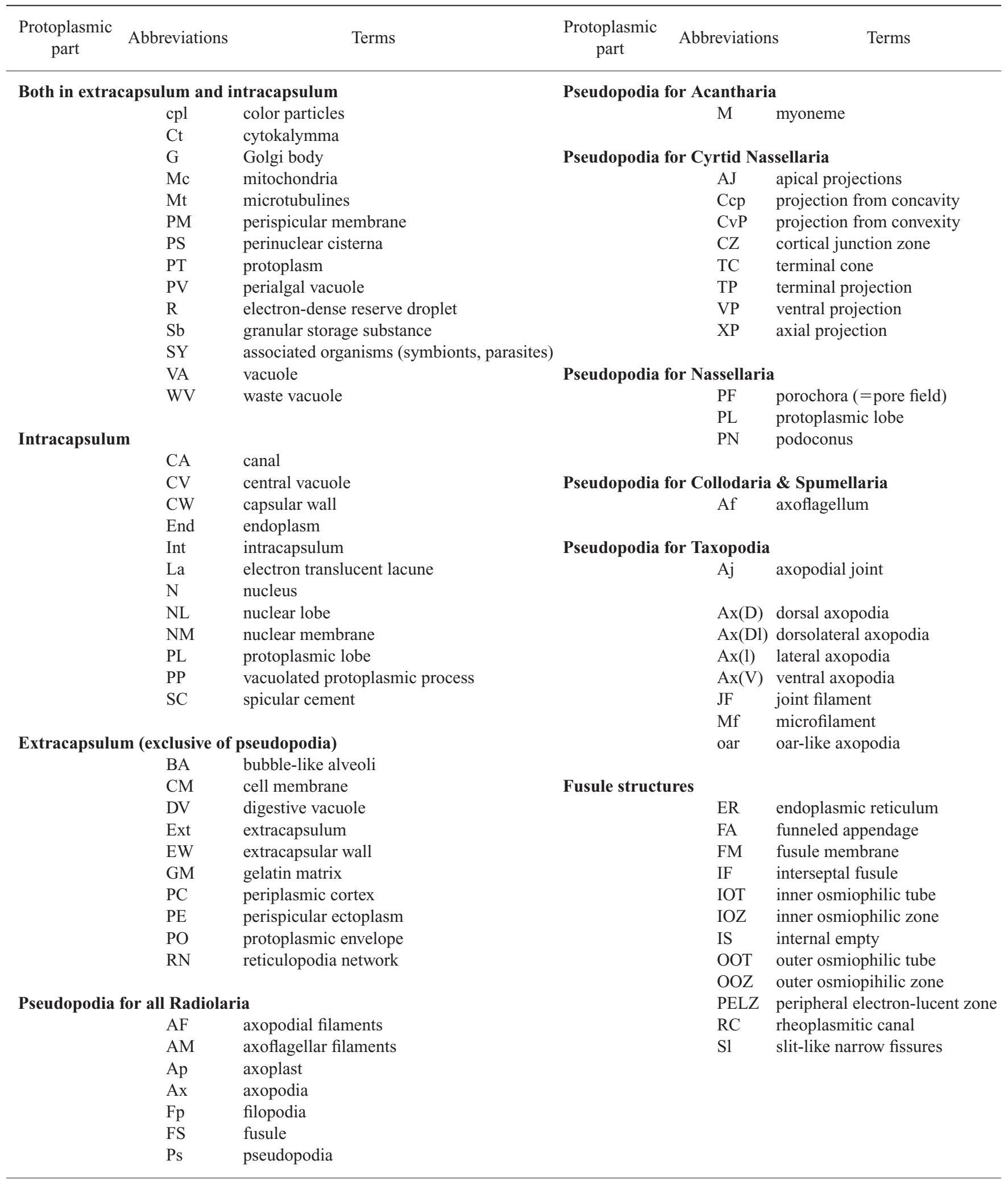


Table 3. Brief definition of pseudopodial systems for Radiolaria. The pseudopodial system is variable and significantly different at the suborder and order-level. Since no list including definitions of pseudopodial systems exists, approximately 25 terms are listed here as essential terms for describing the pseudopodial systems based on more than 50 references.

\begin{tabular}{|c|c|c|}
\hline Terminology & Taxonomy specified & Characters \\
\hline axial projections & Nassellaria & $\begin{array}{l}\text { a single thick pseudopodium from the aperture of the siliceous test, similar to } \\
\text { axoflagellum }\end{array}$ \\
\hline axoflagellar filaments & Radiolaria & $\begin{array}{l}\text { electrically dense matter inside an axoflagellum. This term is usually used } \\
\text { when the component of the filament is not determiend. }\end{array}$ \\
\hline axoflagellum & Spumellaria & a significantly thick, and longer pseudopodia, differing from other pseudopodia \\
\hline axoneme & Radiolaria & $\begin{array}{l}\text { a microtubular axis of shaft, exclusive of the covering membrane, composed of } \\
\text { the }[9(2)+2] \text { arrangement of microtubules }\end{array}$ \\
\hline axoneme bundle & Radiolaria & bundles of axoneme \\
\hline axoplast & Spumellaria, Nassellaria & $\begin{array}{l}\text { a fine fibrillar mass or central granule as a microtubule-organizing center that } \\
\text { may enable microtubules to extend axopodia through fusules }\end{array}$ \\
\hline axopodium & Radiolaria & $\begin{array}{l}\text { pseudopodia stiffened by microtubuline bundles or axonemes inside pseudopo- } \\
\text { dia, and including vacuoles, mitochondria and protoplasmic reticulum }\end{array}$ \\
\hline axopodial filaments & Radiolaria & $\begin{array}{l}\text { electrically dense matter which is connected to the axopodia in the endoplas- } \\
\text { mic reticulum }\end{array}$ \\
\hline axopodial system & Radiolaria & microtubuline network comprising axopodia, axoplast and axopodial filaments \\
\hline filopodium & Spumellaria & temporary, slender protruding part of the ectoplasm, appearing like fine hair \\
\hline intracapsular axopodial system & Radiolaria & $\begin{array}{l}\text { microtubuline bundles of axopodial filaments, axoflagellar filaments and axo- } \\
\text { plast; always situated within the endoplasmic reticulum }\end{array}$ \\
\hline microtubuline & Radiolaria & slender, hollow structure made primarily of tubulin proteins \\
\hline microtubular bundle & Radiolaria & fibrous structure composed of longitudinally aligned $24 \mathrm{~nm}$ microtubules \\
\hline myoneme & Acantharia & $\begin{array}{l}\text { retractable fibrillar, ribbon-like organelles which consist of densely packed 2-3 } \\
\text { nm microfibrils. }\end{array}$ \\
\hline nucleus-axoplast relationship & Spumellaria, Nassellaria & the connecting patterns between axoplast and nucleus \\
\hline perispicular membrane & Acantharia & a protoplasmic membrane that envelopes the acantharian spicules \\
\hline podoconus & Nassellaria & cone-shaped organelle which consists of axopodial filaments \\
\hline projections & Nassellaria & nassellarian pseudopodia \\
\hline projections from concavities & Nassellaria & projections extending from concavities between segments of siliceous test \\
\hline projections from convexities & Nassellaria & projections extending from the middle part of a segment of siliceous test \\
\hline pseudopodium & Radiolaria & $\begin{array}{l}\text { temporary protoplasmic protrusion of radiolarian cell, a common term despite } \\
\text { the different internal structures contained within it }\end{array}$ \\
\hline pseudopodial filament & Radiolaria & $\begin{array}{l}\text { electrically dense matter inside a pseudopodia. This term is usually used when } \\
\text { the component of the filament is not determined. }\end{array}$ \\
\hline reticulopodial network & Collodaria & network of cross-connected pseudopodia \\
\hline terminal cone & Nassellaria & cone-shaped arrangement of terminal projections \\
\hline terminal projections & Nassellaria & fine pseudopodia radiating from the aperture of siliceous test \\
\hline
\end{tabular}

Determination to genus as well as species for Spumellaria requires examination of the internal skeletal structure (mi, ma in Fig. 5A, B) (e.g. De Wever et al. 2001, Suzuki 2006), but this is as yet poorly understood for described species as well as "new species." This taxonomic uncertainty forces radiolarian specialists to apply tentative generic identifications. Many attempts to refine spumellarian classification have been made by micropaleontologists (e.g. Kozur \& Mostler 1972, 1978, 1979, Dumitrica 1984, Petrushevskaya 1984b, De Wever et al. 2001, Afanasieva \& Amon 2006), but these attempts are far from a consensus resolution. Not only that, it is very difficult to assign species names for Spumellaria. A review of available literature shows that for all documented "polycystine" morphotypes (See Fig. 3), 34.7\% (50/144 species) of living Spumellaria (Takahashi 1991) and 50.8\% (33/65 species) of subantarctic Eocene Spumellaria (ca. 30-40 million years ago) (Suzuki et al. 2009a) are still in open nomenclature.

Spumellaria have such complex internal skeleton structure that more than 250 morphological features and terms have been proposed (Petrushevskaya 1984a, Suzuki 1998, Ogane \& Suzuki 2006). However, only a few terms are essential for understanding the principal skeletal morphology of Spumellaria. The skeleton of the superfamily Actinommoidea consists mainly of concentric latticed shells with radial beams (rb in Fig. 5B), radial spines (rs in Fig. 5A), and by-spines (by in Fig. 5A). Concentric latticed shells have a microsphere, a macrosphere, and cortical shells (from innermost to outermost). The microsphere, or inner medullary shell ( $\mathrm{mi}$ in Fig. 5A), and the macrosphere, or outer medullary shell (ma in Figs. 4I, 5A, B), are generally very concentric (cs in Figs. 4I, 5A) in appearance at the 


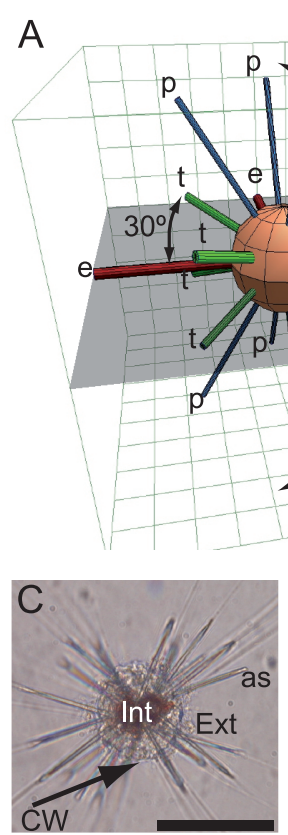

polar view
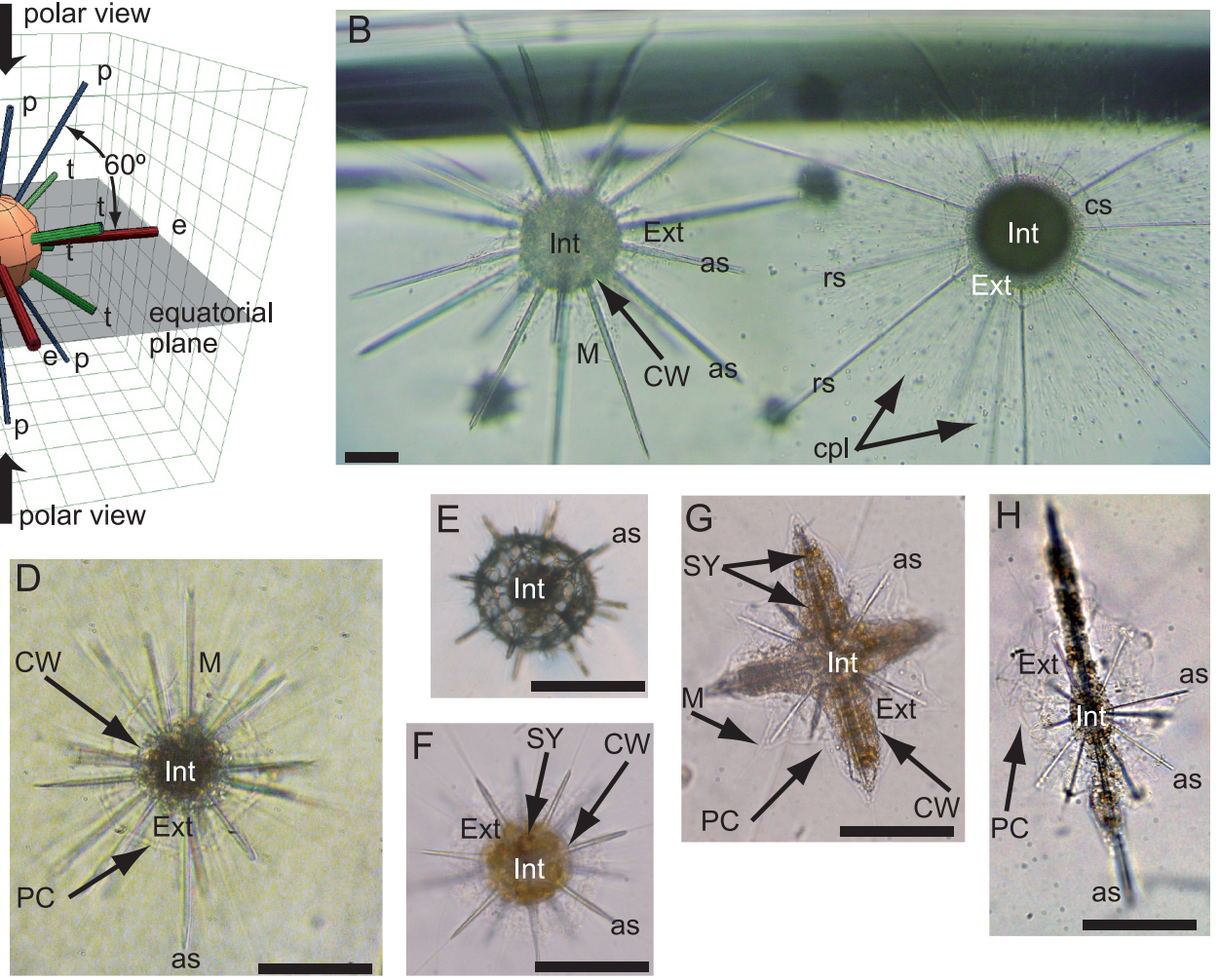

J
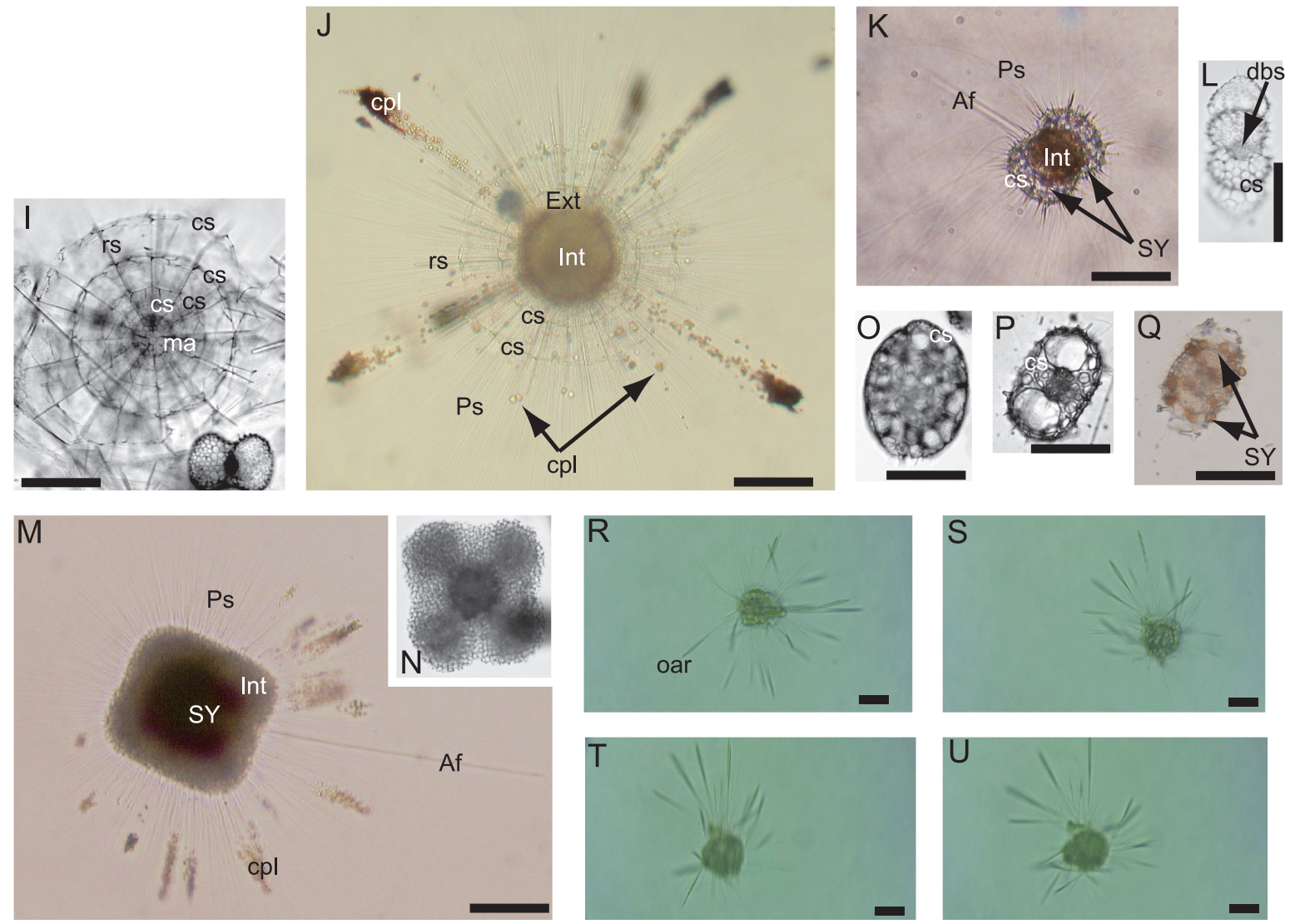

U

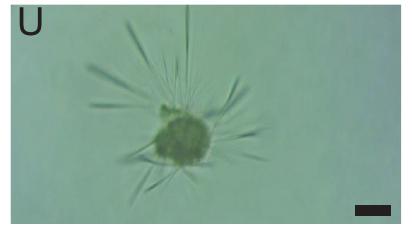


center of the siliceous skeleton (Fig. 5A, B) and are called double medullary shells. The term "medullary shell" is assigned to either the microsphere or macrosphere in cases where it is difficult to decide which is which or it is needless to distinguish between "medullary shells." Spumellarians often have more than three concentric cortical shells (Fig. 4I, J), including double medullary shells; they are called the first, second, and third (and so on) cortical shell, or the innermost, inner, outer, and outermost cortical shell. Radial beams (rb in Fig. 5B) are columnar structures between cortical latticed shells. By-spines (by in Fig. 5A) are tiny spines on the outermost cortical shell (Fig. 5A).

Spumellaria first appeared as early as Ordovician time (ca. 470 million years ago) but did not become especially diverse until the onset of Triassic time (ca. 250 million years ago) (Kozur \& Mostler 1982, De Wever et al. 2001).

\section{Order Taxopodia Fol (Fig. 4R-U)}

Taxopodia comprise a single family, Sticholonchidae, and a single species Sticholonche zanclea. Meunier (1910) described a new species, Sticholonche ventricosa, which was made a synonym of $S$. zanclea by Bernstein (1934). Sticholonche zanclea has siliceous, hollow, isolated spines (Cachon \& Cachon 1978) around pseudopodia and characteristic oar-like axopodia (oar in Fig. 4R) with a heavy tubulin-made axoneme. At first glance, it may be difficult to identify $S$. zanclea as a member of the Radiolaria.

Sticholonche zanclea swims quickly by rowing its oarlike axopodia (oar in Fig. 4R), which has gained it a reputation as a very attractive marine organism. Fig. 4R-U shows the swimming behavior of the same cell at intervals of approximately 30 seconds; the blurred view of the axopodia is partly due to their movement for locomotion. One-way rowing of the axopodia takes as a little as $0.04 \mathrm{~s}$, according to Cachon et al. (1977). Except for S. zanclea, Radiolaria pas- sively float in seawater.

The taxonomic position of Taxopodia has changed since the 1900s (e.g. Cachon \& Cachon 1978). In the early 1900s, Stiasny (1908) identified a capsular wall and thick axopodia in $S$. zanclea and indicated a similarity to Phaeodaria. Radiolaria were originally defined on the basis of protoplasmic structure, regardless of the presence or absence of a mineralized skeleton (e.g. Calkins 1909), and $S$. zanclea was placed in Radiolaria (Poche 1913). Since the 1970s, cytoskeletons have been studied with transmission electron microscopy (TEM), and the architectural similarity between Taxopodia and Heliozoa was exemplified by seven features in Sticholonche. These observations led Cachon \& Cachon (1978) to conclude that Taxopodia should be included within Heliozoa. Recent molecular phylogenetic analysis has revealed that Taxopodia form a single clade with Larcopyle buetschlii Dreyer (Figs. 3, 4M), a spumellarian species (Kunitomo et al. 2006). This is an unexpected result because there is no morphological similarity between Taxopodia (Fig. 4R-U) and Litheloidea (Fig. 4M). There are no fossil records.

\section{Order Collodaria Haeckel (Fig. 5E-I)}

In terms of the history of science, the first recognized Radiolaria were Collodaria (Meyen 1834). Collodaria are solitary (Fig. 5E) or colonial (Fig. 5C, D, F-I) with or without a siliceous skeleton. Colonial Radiolaria are only known within the Collodaria, as is suggested by its name. Collodaria, along with Acantharia, occur as highly abundant, near-surface plankton in the open ocean. The maximum number of collodarian cells recorded exceeds $1.0 \times 10^{5}$ cells $\mathrm{m}^{-3}\left(>540\right.$ colonies $\left.\mathrm{m}^{-3}\right)$ in samples taken from the equatorial Atlantic and Indian oceans (Swanberg 1983).

The classification of Collodaria is mainly that of Haeckel (1862, 1887), Brandt $(1885,1905)$, Strelkov \& Reshetnyak

Fig. 4. A-H. Acantharia. A: Diagram of acantharian spicules, B: Similarity between Acantharia (left; Phyllostaurus cuspidatus) and Spumellaria (right; Diplosphaera hexagonalis), C: Acanthochiasma fusiforme, D: Astrolonche serrata, E: Dorataspidae gen. et sp. indet., F: Pyllostaurus siculus, G: Acanthostaurus henseni, H: Amphilonche elongata. I-Q. Spumellaria. I, J: Arachnosphaera myriacantha, K, L: Didymocyrtis tetrathalamus, M, N: Spongaster tetras tetras, O: Larcopyle buetschlii, P, Q: Tetrapyle octacantha. R-U. Taxopodia. Sticholonche zanclea. Scale bars for B, I-U are $100 \mu \mathrm{m}$ and for C-H are $50 \mu \mathrm{m}$. See Tables 1 and 2 for abbreviations. These figures show typical morphology of Acantharia (Fig. 4B-H), Spumellaria (Fig. 4I-Q) and Taxopodia (Fig. 4R-U). Spicules of Acantharia are systemically arranged as illustrated in Fig. 4A. Four equatorial spicules marked as "e" (red color) are placed on the equatorial plane, the other eight tropical spicules as " $\mathrm{t}$ " (green color) arise at an angle of 30 degrees from the equatorial plane, and the remaining eight polar spicules are placed at an angle of 60 degrees from the equatorial plane. This system is named Müller's law. They are easily differentiated from Spumellaria by the presence of strontium sulfate skeletons, but actual cells of Acantharia (left cell in Fig. 4B) and Spumellaria (right cell in Fig. 4A) bear superficial similarity to each other. However, based on Müller's law, these two cells can be distinguished. Acantharia appear to possess 20 spicules (Fig. 4C-H), but the Suborder Holacanthida (Fig. 4C, D) has 10 spicules which intersect at the center of the cell. The Holacanthida are an exception to Müller's law. The other acantharian suborders have 20 spicules that are joined to each other at the center of the cell. Some acantharians have a spherical shell similar to the spherical Spumellaria as shown in Fig. 4E. The shape of spumellarian skeletons varies from spherical (Fig. 4I), drum-shaped (Fig. 4L), ellipsoidal with spiral internal structure (Fig. 4O), box-shaped (Fig. 4P, Q), to flat-shaped (Fig. 4M, N), but they commonly have a centrally concentric structure. The skeletal structure of Spumellaria is so complex that it is difficult to identify them if they are live (Fig. 4J, K, O, P). As shown in Fig. 4R-U, Taxopodia actively swim. 

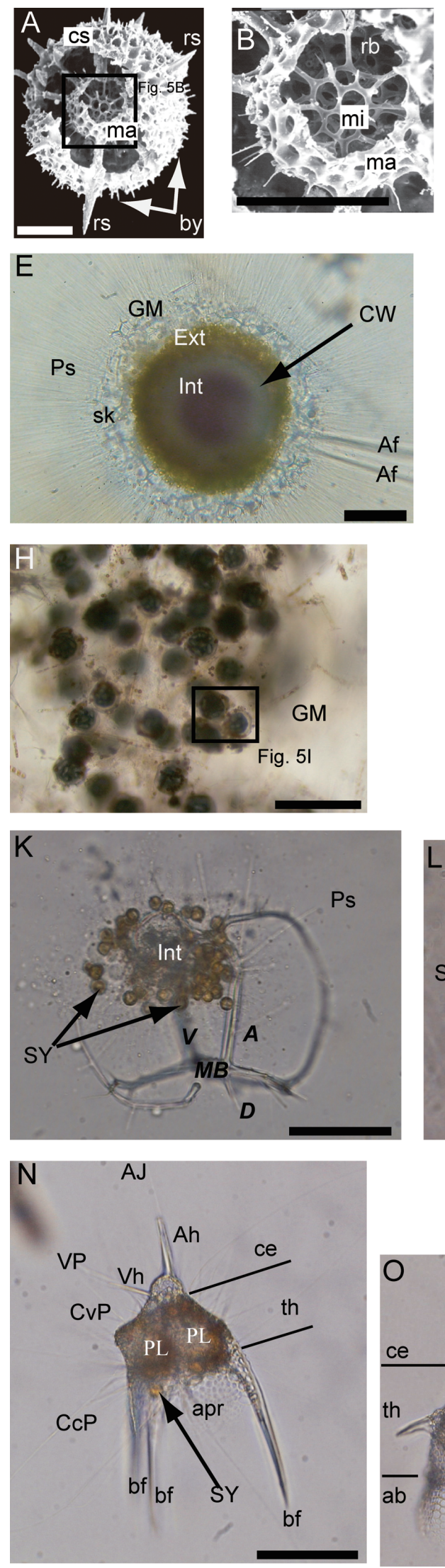
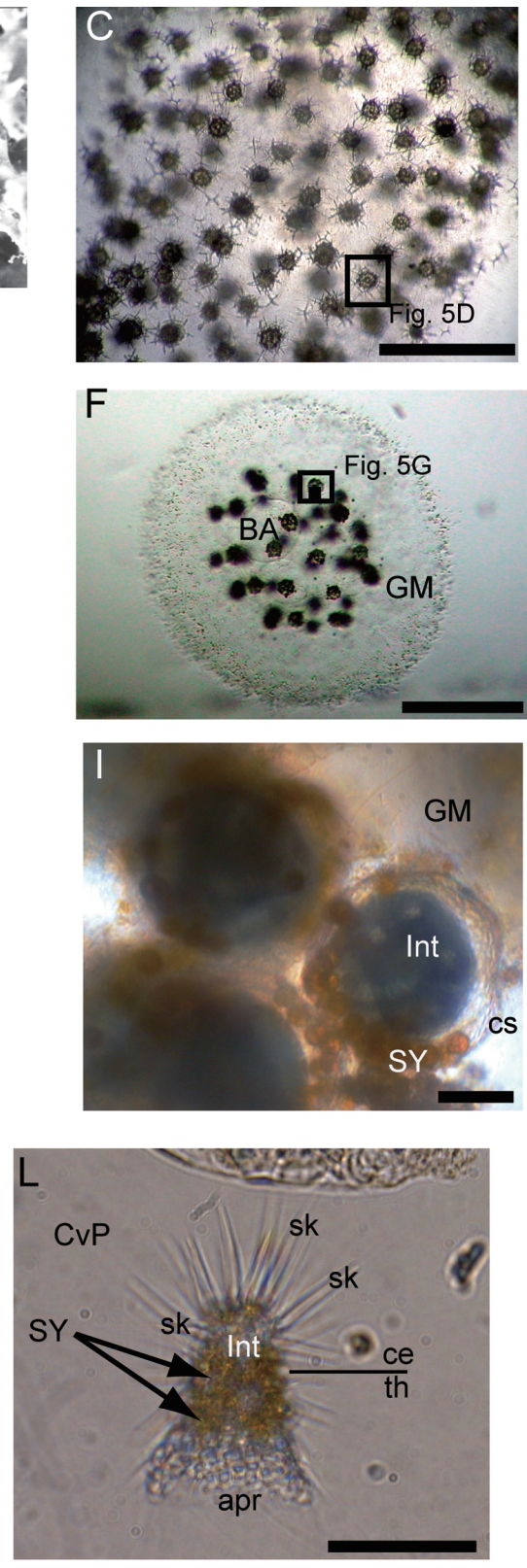
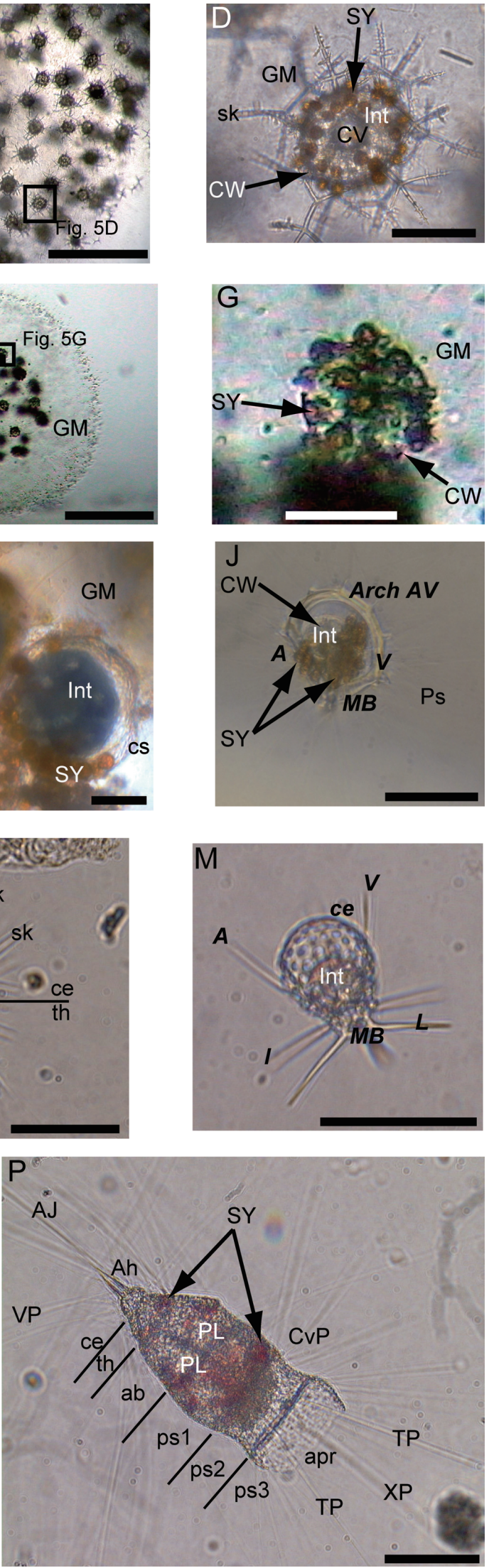
(1971), and Anderson (1983). Thalassosphaeridae is a solitary collodarian, possessing isolated tiny spicules (sk in Fig. 5E) around the cell. Similar individuals with many isolated, tiny spicules (sk in Fig. 5D) are also observed in Sphaerozoidae (Fig. 5D), but they always form colonies, as shown in Fig. 5C. Isolated, tiny spicules are occasionally found in sediments and seawater, but cannot be differentiated as solitary Thalassosphaeridae or colonial Sphaerozoidae. Cells of Collosphaeridae have a simple, single, thinwalled spherical or subspherical latticed shell (cs in Fig. 5I) and most make colonies (Fig. 5H). Collosphaeridae is a major identifiable group of fossil Collodaria. The same species forms a variety of gelatinous colony shapes, and colony size ranges from several tens of microns to a few meters. For instance, Collozoum longiforme Swanberg \& Harbison and Collozoum caudatum Swanberg \& Anderson reach lengths of up to 2-3 m with tail-like strands of waste material (Swanberg \& Harbison 1980, Swanberg \& Anderson 1981).

Collodaria were used to study fine protoplasmic structures that are typical of Radiolaria (Huth 1913, Anderson \& Botfield 1983), because the structures are easily observed in ultrathin sections due to the absence of or minimal presence of hard parts. However, there is some doubt as to whether Collodaria can be regarded as a typical representative of "polycystine" Radiolaria (see Fig. 3). The reason for this is that most Radiolaria are solitary, whereas most Collodaria are colonial.

Collodaria are commonly associated with algal symbionts (SY in Fig. 5D, G, I) and a nutrient-based alga-host interaction has been demonstrated in laboratory experi- ments (Anderson, 1978b). Accordingly, Collodaria are exclusively common in oligotrophic environments (Swanberg 1983). Collodaria appeared in the Eocene (339-558 million years ago) (De Wever et al. 2001).

\section{Order Nassellaria Ehrenberg (Fig. 5J-P)}

Nassellaria are probably the best-known "polycystine" Radiolaria possessing conical siliceous tests with segmentations (e.g. Fig. 5P). Nassellaria are traditionally subdivided into two suborders: Spyrida Ehrenberg (Fig. 5J, K) and Cyrtida (or Cyrtellaria) Haeckel (Figs. 2, 5L-P). Spyrida are characterized by a skeleton that generally possesses a sagittal ring. The sagittal ring is the D-shaped ring that is comprised of a median bar ( $\boldsymbol{M B}$ in Fig. $5 \mathrm{~J}, \mathrm{~K})$, apical ray ( $\boldsymbol{A}$ in Fig. 5J, K), vertical ray ( $\boldsymbol{V}$ in Fig. $5 \mathrm{~J}, \mathrm{~K}$ ), and an arch connecting the apical and vertical rays (Arch $A V$ in Fig. 5J) and latticed lateral chambers that form a bilobate cephalis (Fig. $5 \mathrm{~K}$ ), whereas Cyrtida have a skeleton with a conical (Fig. 5O, P) or cap-shaped test (Fig. 5L, M), consisting of uniserially and usually rectilinearly arranged segments (Petrushevskaya 1971, Sanfilippo et al. 1985). Superficial features of Spyrida (Fig. 5J, K) appear quite different from those of Cyrtida (Fig. 5L-P), but they have a common skeletal structure. It is surprising that the same bony framework including the apical ray ( $\boldsymbol{A}$ in Fig. 5J, K), vertical ray ( $\boldsymbol{V}$ in Fig. 5J, K), and median bar ( $\boldsymbol{M B}$ in Fig. 5J, K, M) is encrypted in the first segment (cephalis) (ce in Fig. 5L-P) of multi-segmented Nassellaria. This framework is referred to as the "initial spicular system" or "cephalic structure" which is considered a very conservative structure in family-

Fig. 5. A, B. SEM photographs showing the internal structure of the spumellarian Actinomma sp. from the Miocene (ca. 14 million years ago). A: entire view showing the internal skeletal structure. B: close-up view of double medullary shells from the open box in Fig. 5A. C-I. Collodaria. C: colony form of Sphaerozoum fuscum, D: close-up view of a single radiolarian cell from the open box in Fig. 5C, E: solitary form of Thalassosphaera curvicornis, F: colony form of Collozoum inerme, G: close-up view of a single radiolarian cell from the open box in Fig. 5F, H: colony form of Collosphaera tuberosa, I: close-up view of single radiolarian cells from the open box in Fig. 5H. J-M. Spyrid Nassellaria. J: Zygocircus productus, K: Acanthodesmia vinculata, L: Lophophaena hispida, M: Peromelissa phalacra. N-P. Cyrtid Nassellaria. N: Pterocanium praetextum, O: Lipmanella dictyoceras, P: Eucyrtidium hexagonatum. Scales for A, B, D, G, I, J, L, M are $50 \mu \mathrm{m}$, for C, F, H are $0.5 \mathrm{~mm}$, and for E, K, N-P are $100 \mu \mathrm{m}$, respectively. See Tables 1 and 2 for abbreviations. Superfamily Actinommoidea (Spumellaria) are characterized by the possession of a double medullary shell (microsphere and macrosphere) (Fig. 5A, B). The architecture of the microsphere is considered to be of a common pattern within the same family. Fig. 5C-I represents three major families of Collodaria. Collodaria are characterized by a colonial form with numerous radiolarian cells (Fig. 5C, F, H), but the family Thalassosphaeridae (Fig. 5E) is an exception being a solitary collodarian group. Thalassosphaeridae have a gelatinous matrix (GM in Fig. 5E) and isolated siliceous spicules (sk in Fig. 5E) as in the Sphaerozoidae (Fig. 5D). It is extremely difficult to differentiate between the Thalassosphaeridae and Sphaerozoidae after their protoplasmic part is lost. Identifiable collodarians largely belong to the family Collosphaeridae (Fig. 5H, I) because this family has a spherical cortical shell (rarely two shells). Collodaria commonly harbor algal symbionts (SY in Fig. 5D, G, I). Spyrid Nassellaria (Fig. 5J, K) appear to be different from the Cyrtid Nassellaria (Fig. 5L-P), but the internal spicular system composed of $\boldsymbol{A}, \boldsymbol{V}$ and $\boldsymbol{M B}$ is commonly recognized throughout the Spyrida (Fig. 5J, K) and Cyrtida (Fig. 5M). The internal spicular system is the main distinguishing feature for the both Spyrida and Cyrtida at the family-level. Spyrida are characterized by the presence of a "D-ring" which is comprised of $\boldsymbol{A}, \boldsymbol{A r c h}-\boldsymbol{A} \boldsymbol{V}$ or a relevant arch, $\boldsymbol{V}$ and $\boldsymbol{M B}$ (Fig. 5J, K). In the Cyrtid Nassellaria, the Superfamily Plagiacanthoidea have a significantly large cephalis (ce in Fig. 5L, M), compared with the overall size of the skeleton. Cyrtids have a smaller cephalis (Fig. 5N-P). Nassellarians shown here are easily recognizable with their yellowish brown associated organisms (SY in Fig. 5J-L, N-P) and yellowish to reddish matter outside the protoplasmic lobes (PL in Fig. 5N-P). 
or genus-based fossil evidence (Petrushevskaya 1971). Although this assumption is still in dispute among micropaleontologists, the current scheme for Nassellaria at higher taxonomic levels is mainly based on the initial spicular system as well as morphologic changes through time (De Wever et al. 2001). This structure is rarely used for species classification. Other important morphological terms are "cephalis" (ce in Fig. 5L-P), "thorax" (th in Fig. 5L, N-P), "abdomen" (ab in Fig. 5O, P), and "post-abdominal segments" (ps1, ps2, ps3 in Fig. 5P) from the apex of the test to the widened aperture.

Classification of Nassellaria at the species level seems to have gained consensus among radiolarian specialists, but genus and family designations are still disputed. For instance, a well-known extant high-latitude marker species, Cycladophora davisiana Ehrenberg, has been placed in one of four genera. Even worse, a given genus can be attributed to a variety of families. Such confusion is mainly due to insufficient traces of phylogeny at the species-level in each genus. Since taxonomic classification at the genus and family levels is still confused, we maintain that discussion of nassellarian radiolarians must be at the species level. Although taxonomic confusion continues, 52 families and 400 genera (fossil and living) are listed in Nassellaria (De Wever et al. 2001). The continuous fossil records go back to the Early Triassic (250 million years ago), although isolated occurrences of nassellarian-like "polycystine" Radiolaria (families Archocyrtiidae and Popofskyellidae) are known between the Late Devonian (380 million years ago) to Late Carboniferous (315 million years ago) (Cheng 1986).

\section{Cytology}

The protoplasm is roughly divided into a nucleus/nuclei $(\mathrm{N}$ in Fig. 6A-D), nuclear wall, endoplasm (End in Fig. 6A, $\mathrm{D})$, capsular wall (or capsular membrane) (CW in Fig. 6A-D), ectoplasm (Ect in Fig. 6A-D), and pseudopodia (Table 3). The capsular wall divides the protoplasm into an endoplasm and an ectoplasm. An interconnecting organelle between the endoplasm and ectoplasm termed the fusule (FS in Fig. 6B-D) is also characteristic of Radiolaria. The most significant feature of the radiolarian protoplasm is a dense, colored section that corresponds to the protoplasm in the capsular wall. For practical recognition of radiolarian protoplasm, the region that includes the nucleus and endoplasm is called the "intracapsulum" (=intracapsular protoplasm, or central capsule) (Int in Figs. 4A-H, J, K, P, 5D, E, I, $\mathrm{K}-\mathrm{M}$ ), whereas the protoplasm outside the capsular wall is the "extracapsulum" (=extracapsular protoplasm) (Ext in Figs. 4B-D, F-H, J, 5E) (Campbell 1954, Anderson 1983, De Wever et al. 2001).

Taxopodia (Fig. 4R-U) are distinctly different from all other radiolarians because of the absence of a capsular wall, which is an important characteristic of the Radiolaria. The thick protoplasmic wall of Taxopodia was considered to be a capsular wall in early studies, but this is now regarded as a nuclear wall. This was established to be a nuclear wall because of the absence of other protoplasmic organelles (Hollande et al. 1967). Cachon \& Cachon (1978) demonstrated the presence of a thick, double nuclear membrane $(600 \mathrm{~nm}$ in thickness) called the "nuclear capsule."

\section{Intracapsulum}

Nucleus: The nucleus of Radiolaria is interesting because of its spatial relationship within the skeleton. Spicules protrude through the center in acantharian species, so the nucleus is never found there (Fig. 6A). The intracapsulum of some Symphyacanthoidea (Haliommatidium and Dicranophora) contains a single large nucleus that is probably polyploid during the trophont life stage, whereas there are numerous small round or oblong nuclei in all other Acantharia (N in Fig. 6A) (Febvre 1977, Febvre et al. 2000, Suzuki et al. 2009b).

A similar multinucleated intracapsulum is also observed in some colonial Collodaria (Sphaerozoum fuscum Meyen, Collosphaera globularis Haeckel, Collozoum caudatum Swanberg \& Anderson) at both reproductive and trophont stages (N in Fig. 6C) (Anderson 1976a, 1978b, Swanberg \& Anderson 1981, Suzuki et al. 2009b). The diameter of the nuclei ranges from 5 to $20 \mu \mathrm{m}$. Other collodarian species, including Thalassicolla nucleata Huxley, have a single nucleus at the center of the intracapsulum (Fig. 7B) (Huth 1913).

A single central nucleus is common in Spumellaria (Fig. 7B, 7D-F) (Hollande \& Enjumet 1960, Suzuki et al. 2009b). In some spongiose Spumellaria (e.g. Styptosphaera spumacea Haeckel), a dense siliceous skeletal meshwork is fully developed inside the test and the 20-60- $\mu$ m-diameter nucleus is located at the center (Swanberg et al. 1990). Actinommoidea possess double medullary shells (with a siliceous skeletal part in the center of the test), and the nucleus wraps around the microsphere and is encrypted in the macrosphere (Sugiyama \& Anderson 1998a).

The Nassellaria suborder Cyrtida consist of a cephalis (ce in Fig. 8A-C), thorax (th in Fig. 8A-C), abdomen (ab in Fig. 8A, B), and post-abdominal segments (ps1, ps 2 in Fig. $8 \mathrm{~A}, \mathrm{~B}$ ), but this segmentation does not appear to correspond to the protoplasmic structure very well (Fig. 8A-C). The apex of the intracapsulum is always in the cephalis, but the entire nucleus may not always be in the cephalis $(\mathrm{N}$ in Fig. 8B, C) (Hollande \& Enjumet 1960, Sugiyama \& Anderson 1997). In contrast, the nucleus in the Nassellaria suborder Spyrida (Acanthodesmia vinculata (Müller) and Lithocircus reticulatus (Ehrenberg)) is spherical to elliptical (N in Fig. 7G, H) (Sugiyama \& Anderson 1998b), probably due to a lack of skeletal coverage (Fig. 5J, K).

The shape and position of the nucleus are different in Taxopodia from all other Radiolaria (N in Fig. 7C). Sticholonche zanclea is generally elongate in shape with an elongated nucleus that is always positioned on the proto- 

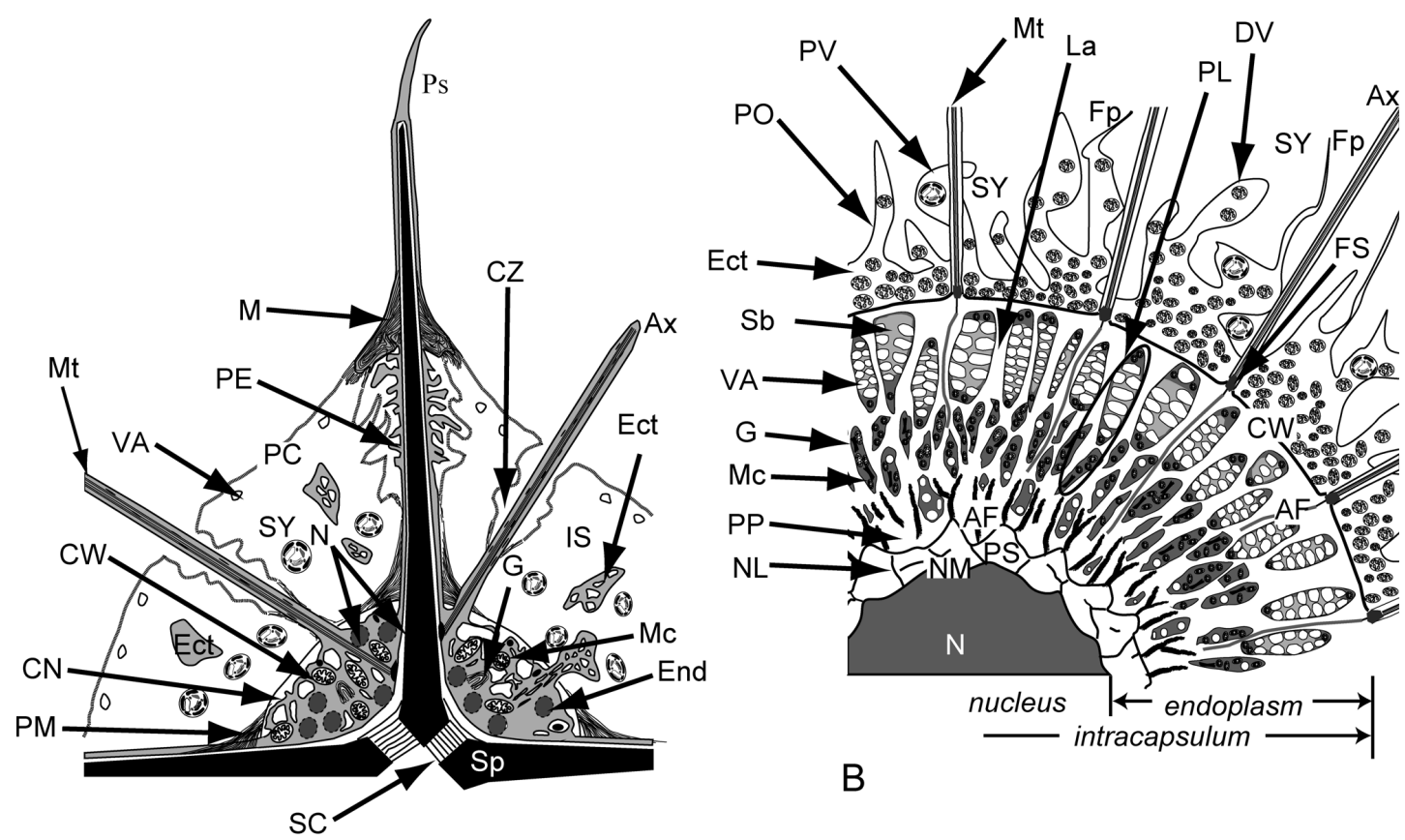

B

A

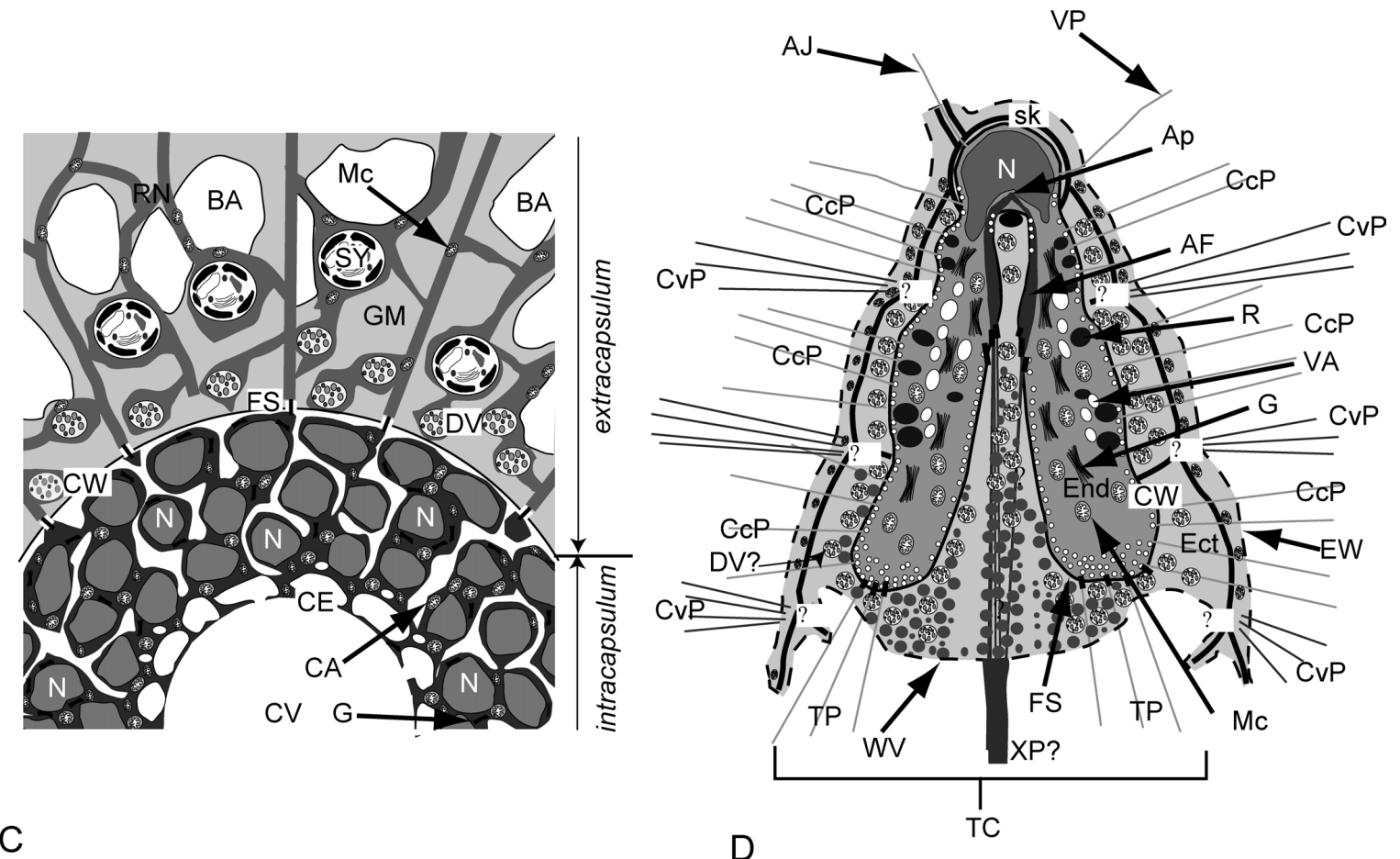

Fig. 6. Generalized protoplasmic structure of Radiolaria. A. Acantharia (from Febvre 1974, 1981, Febvre et al. 2000), B. Spumellaria (from Anderson 1976b, De Wever et al. 2001), C. Collodaria (from Anderson 1976a, Anderson et al. 1999), D. Nassellaria (from Cachon \& Cachon 1971, Sugiyama \& Anderson 1997, Matsuoka 2007). See Tables 1 and 2 for abbreviations. It is noteworthy that acantharian spicules ( $\mathrm{Sp}$ in Fig. 6A) are separated from the protoplasmic part by perispicular membrane (PM in Fig. 6A). As shown in Fig. 6A, the perispicular membrane (PM), myoneme (M), and periplasmatic cortex (PC) are the same membrane which can elastically stretch and move. For Spumellaria (Fig. 6B), the relationship between the siliceous skeleton and the protoplasmic part is not fully understood. Zonal differentiation of protoplasm is one of the characteristics of the Spumellaria (Fig. 6B). Collodaria are characterized by the presence of a gelatinous matrix (Fig. 5C). Cyrtid Nassellaria are characterized by the presence of protoplasmic lobes (PL in Fig. 5D). 

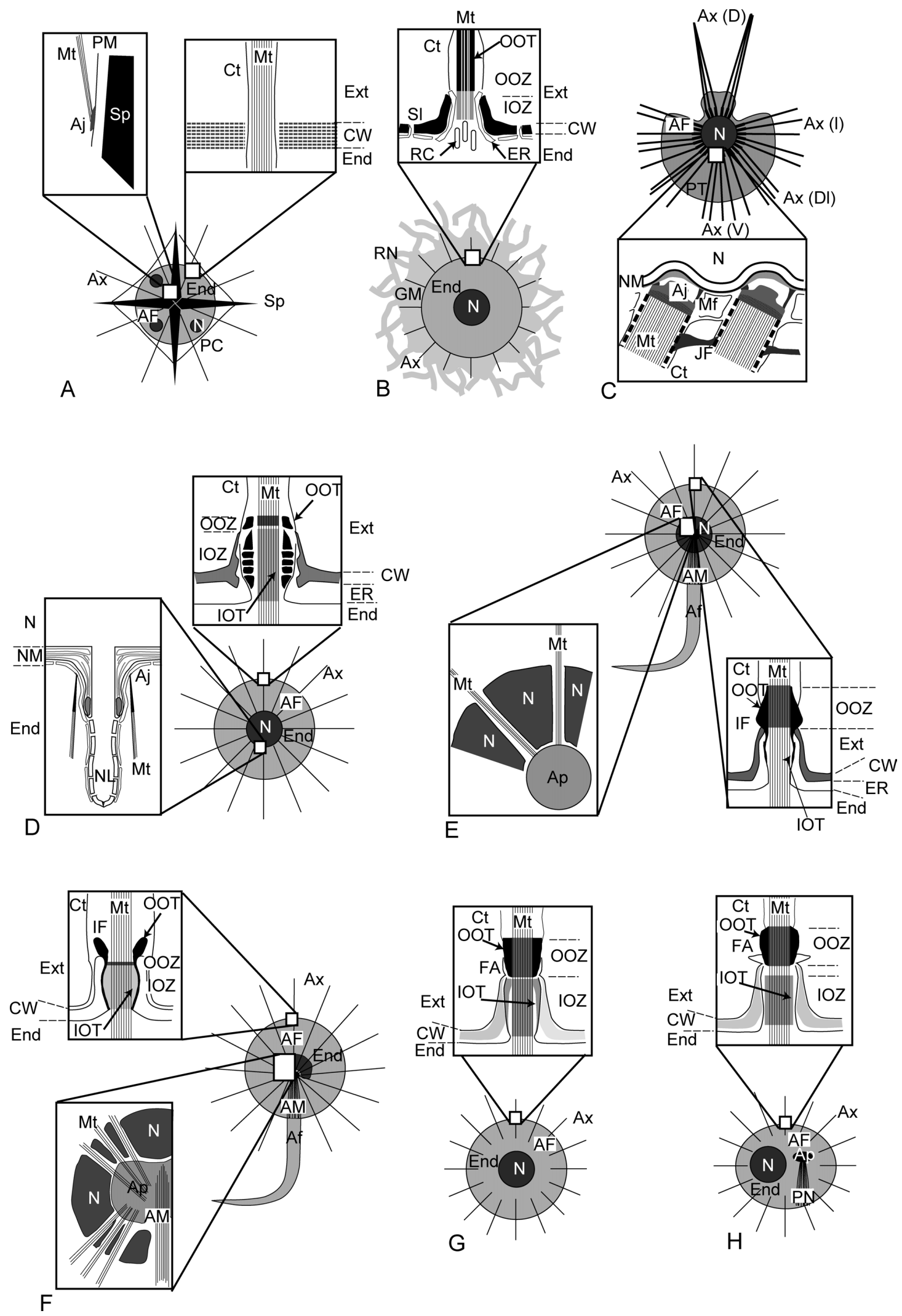

F 
plasm "backbone" (Cachon \& Cachon 1978). Figure 7C shows the axial transverse section and the lateral view of $S$. zanclea, as shown in Fig. 4R-U.

Endoplasm: The endoplasmic reticulum (ER) of Radiolaria contains a variety of organelles including Golgi bodies ( $\mathrm{G}$ in Fig. 6A, B), mitochondria (Mc in Fig. 6A-D), vacuoles, and reserve droplets with a granular storage substance matrix ( $R$ in Fig. 6D). Free ribosomes are liberally distributed throughout the ER (Anderson 1977). In some colonial Collodaria and Spumellaria, orthorhombic or dipyramidal crystals are scattered in the endoplasm (Müller 1858, Haeckel 1862, Hollande \& Enjumet 1960). These crystals are celestite (strontium sulfate), according to spectral analysis and crystal morphology of Sphaerozoum neapolitatum Brandt (Hollande \& Martoja 1974). Similar crystals have also been obtained from Acantharia (Bernstein et al. 1999).

In Acantharia, the ER is clearly parceled with the capsular wall (CW in Fig. 6A) in three suborders (Symphyacanthida, Chaunacanthida and Arthracanthida) but protrudes outside the intracapsulum as ectoplasm through a relatively large aperture on the capsular wall (Ect in Fig. 6A) (Febvre et al. 2000). The ER of Collodaria surrounds the nucleus when a single large nucleus is present, whereas the ER of Collodaria, which is within the intracapsulum, is covered with a wrinkled protoplasmic envelope to form a canal (CA in Fig. 6C) or is an irregularly shaped protoplasmic envelope (Anderson et al. 1999). In colonial Collodaria, these spaces may enhance the exchange of material and gases, such as oxygen and carbon dioxide, with the surrounding environment (Anderson et al. 1999).

The ER of Spumellaria is illustrated for spherical forms only in Figs. 6B, 7D-F, and is packed in radially elongated protoplasmic lobes inside the intracapsulum. In some species, the Golgi bodies ( $\mathrm{G}$ in Fig. 6B) and mitochondria (Mc in Fig. 6B) tend to be concentrated in the inner portion of the protoplasmic lobe (PL in Fig. 6B), whereas many vacuoles (VA in Fig. 6B) and granular storage substances are present in the outer portion, suggesting spherically symmetric, functionally differentiated tissue in the spherical Spumellaria. A similar protoplasmic structure is recognized in spyrid Nassellaria (Sugiyama \& Anderson 1998b).

The ER of Cyrtida is divided into four to six protoplasmic lobes (PL in Fig. 5N-P). Relatively large electrondense reserve droplets ( $\mathrm{R}$ in Fig. $6 \mathrm{D}$ ) are recognized in the lobe (Sugiyama \& Anderson 1997), and small vacuoles are scattered near the capsular wall (VA in Fig. 6D).

\section{Capsular wall and associated structures}

Capsular wall: "Capsular membrane" is the most widely used name for the protoplasmic divider between the endoplasm and ectoplasm. Holacanthida (Fig. 4C), Symphyacanthida (Fig. 4D), and Chaunacanthida (not figured) (Acantharia) possess thin fibrillar layers (CW in Fig. 7A) instead of a firm chitinous or pseudochitinous membrane (CW in Fig. 7B-H), and subsequently, Febvre et al. (2000) recommended using the term "capsular wall," which includes the terms "capsular membrane" and "fibrillar layer."

The capsular wall is a firm, chitinous or pseudochitinous cellular envelope. This firm membrane can remain intact for several months after death under normal seawater conditions, and this property is occasionally misunderstood as evidence of life. The thickness of the capsular wall as mea-

Fig. 7. Schematic of the microtubule systems of Acantharia, Collodaria, Taxopodia, Spumellaria, and spyrid Nassellaria. A. Acantharia (from Febvre \& Febvre-Chevalier 1982, Febvre et al. 2000), B. Exo-axoplastid Collodaria (from Anderson 1976a, b, c, Cachon \& Cachon 1976a, 1977, Swanberg \& Anderson 1981, Anderson et al. 1999). C. Taxopodia (from Hollande et al. 1967, Cachon et al. 1977), D. Cryptoaxoplastid spherical Spumellaria (from Cachon \& Cachon 1972b), E. Centroaxoplastid Spumellaria (Actinosphaera and Rhizosphaera) (from Hollande \& Enjumet 1960, Cachon \& Cachon 1972a), F. Periaxoplastid spherical Radiolaria (spumellarian Cenosphaera reticulata) (from Cachon \& Cachon 1972b), G. Spyrida of the Nassellaria (Lithocircus reticulatus) (from Sugiyama \& Anderson 1998b), H. Spyrida of the Nassellaria (Acanthodesmia vinculata) (from Sugiyama \& Anderson 1998b). See Tables 1 and 2 for abbreviations.

The microtubule system of Radiolaria is considered to be important because the axopodial system is a unique protoplasmic structure. Studies on the pseudopodial system mainly focus on fusules, the passage structure in the capsular wall (CW) between the intracapsulum and extracapsulum and the relationships between the intracellular axopodial system (AP, AM and Mt) and nucleus (N). The axopodia of Acantharia (Fig. 7A) arise from the perispicular membrane (PM) but are not attached to the acantharian spicules (Sp). Fusules of Acantharia are very simple (upper left inbox of Fig. 7A), differing from other Radiolaria (Figs. 7B - H, 8D). In Collodaria (Fig. 7B), a bundle of microtubuline (Mt) is present inside the axopodia but is absent in the intracapsulum. Taxopodia (Fig. 7C) have thick, oar-like axopodia (lower inbox of Fig. 7C) which arise from the nuclear membrane (NM). Oarlike axopodia can simultaneously move with axopodial joints (Aj) and joint filaments (JF). Spherical Spumellaria (Fig. 7D-F) have different arrangements of nucleus (N) and axoplast (AP). Axoplasts are absent in cryptoaxoplastids (Fig. 7D), present in the center of the protoplasm in centroaxoplastids (Fig. 7E), and situated beside the nucleus or open in one direction in periaxoplastids (Fig. 7F). The fusule structure also differs in cryptoaxoplastids, centroaxoplastids and periaxoplastids (Inbox figures around capsular wall [CW] in Fig. 7D-F). The microtubule system of spyrid Nassellaria (Fig. 7G, H) is similar to cryptoaxoplastid Spumellaria (Fig. 7D) regardless of the phylogenetically close relationship to cyrtid Nassellaria (Fig. 8A-C). Densely thick outer osmiophilic tubes (OOT) of spyrid Nassellaria (inbox of Fig. 7G, H) are similar to those in centroaxoplastid Spumellaria (lower right inbox of Fig. 7E) rather than cryptoaxoplastid Spumellaria (upper inbox of Fig. 7D). 

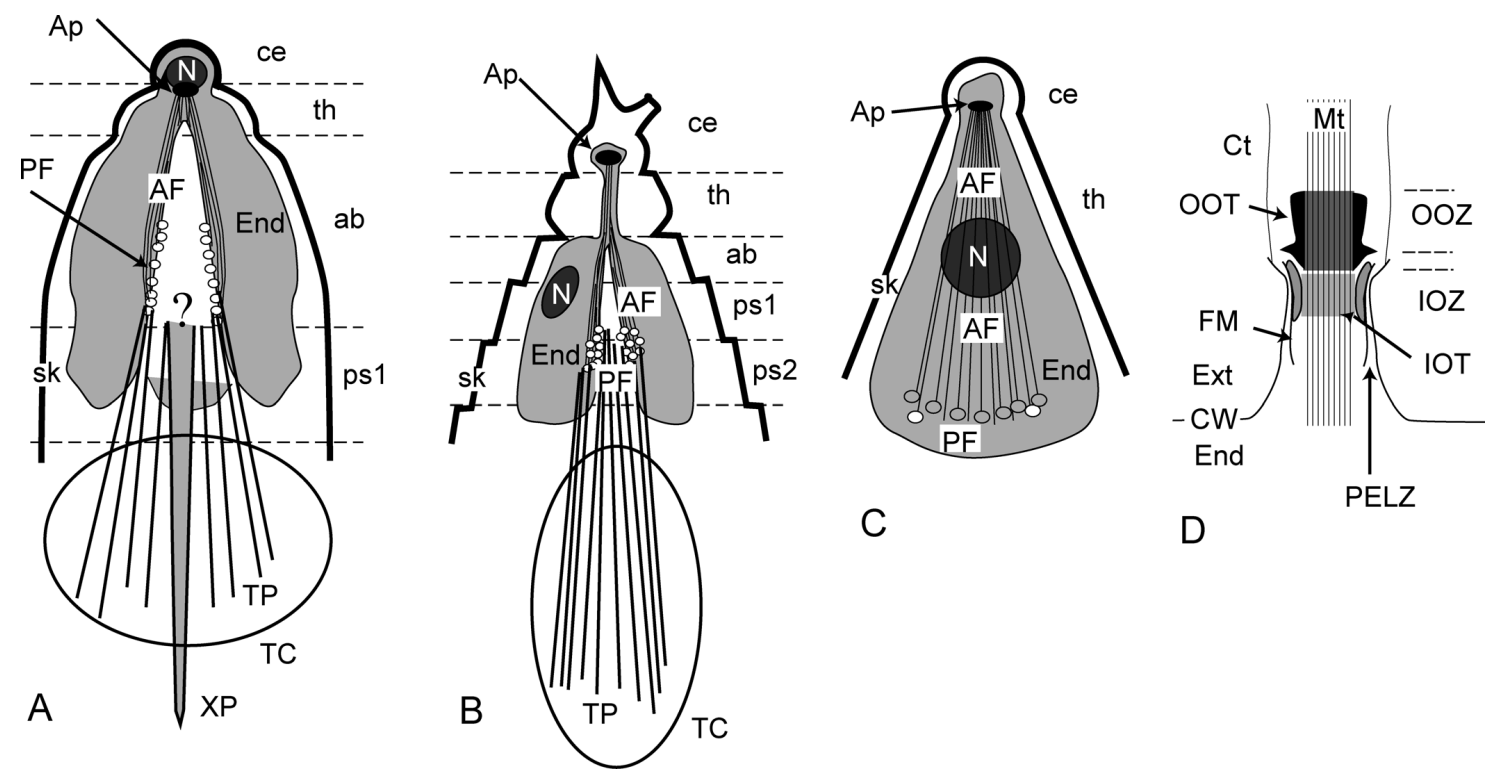

Fig. 8. Schematic of the microtubule system of cyrtid Nassellaria. A. Eucyrtidium (from Cachon \& Cachon 1971, Sugiyama \& Anderson 1997), B. Spirocyrtis scalaris (from Sugiyama \& Anderson 1998b), C. Litharachnium (from Cachon \& Cachon 1971). D. fusule structure of podoconus of cyrtid Nassellaria (Eucyrtidium, Litharachnium, Pterocorys, and Spirocyrtis) (from Cachon \& Cachon 1971, Sugiyama \& Anderson 1997). See Tables 1 and 2 for abbreviations. Axoplast (Ap) of cyrtid Nassellaria is positioned in the cephalis (Fig. 8A-C). The nucleus is generally placed in the cephalis, and it is rarely placed outside of the cephalis. It is noteworthy that endoplasm (End) is not restricted to any segments like thorax (th), abdomen (ab) and postabdominal segments (ps1, ps2). Fusule of cyrtid Nassellaria (Fig. 8D) is similar to that of spyrid Nassellaria (Fig. 7G, H) except for the thickness of the capsular wall $(\mathrm{CW})$.

sured by TEM is between $30 \mathrm{~nm}$ and $500 \mathrm{~nm}$ in Radiolaria, depending on the structure. It is notable that the protoplasm between the endoplasm and ectoplasm facilitates communication through tunnel-like complex collars called fusules and slit-like narrow fissures (SI in Fig. 7B).

The capsular wall of Acantharia looks ambiguous or very thin under light microscopy (Fig. 4C-H). Febvre et al. (2000) reported that Holacanthida, Symphacanthida, and Chaunacanthida have ambiguous capsular walls consisting of a thin fibrillar layer, but that the total thickness of that of Heteracon muelleri is not so thin $(30 \mathrm{~nm})$ (Febvre et al. 2000) compared with the thicknesses in other Radiolaria. The ambiguous nature of the fibrillar layer is due to its structure. As illustrated in Febvre et al. (2000), the acantharian capsular wall is composed of a multilayered meshwork sheet $(20-30 \mathrm{~nm}$ in thickness) of hexagonally arranged " $9 \times 2+1$ " axonemes. The acantharian capsular wall continues with a perispicular membrane and periplasmic cortex (CW in Fig. 7A). The protoplasmic structure of the perispicular membrane and periplasmic cortex (Febvre 1972, 1973) are also similar to that of the capsular wall.

The remaining "polycystine" Radiolaria (Collodaria, Spumellaria, and Nassellaria) have a single-layered (CW in Figs. 7B, E, F, 8D) or multilayered (CW in Fig. 7D, G, H) organization. Spumellaria and spyrid Nassellaria possess a thick capsular wall generally composed of several layers (dense thin membrane, electrically transparent membrane, electrically gray membrane, and dense thin membrane from the inner to outer layers), whereas cyrtid Nassellaria and Collodaria have a very thin electrically dense membrane (Anderson 1976c, Anderson et al. 1999, Sugiyama \& Anderson 1997). The capsular walls are $25 \mathrm{~nm}$ thick in Hexalonche amphisiphon (Haeckel) (Spumellaria) (Anderson \& Botfield 1983), 30-40 nm in Collodaria (e.g. Anderson 1976c, Anderson et al. 1999), 30-40 nm in cyrtid Nassellaria (Sugiyama \& Anderson 1997), 60-80 nm in Didymocyrtis tetrathalamus (Haeckel) (Spumellaria) (Sugiyama \& Anderson 1998a), and 300-500 nm in spyrid Nassellaria (Sugiyama \& Anderson 1998b).

Fusule and fissure: The capsular wall is a substantial barrier between the endoplasm and ectoplasm, but very fine protoplasm can connect through fusules and fissures (upper inbox of Fig. 5B, D, G, H; lower inbox of Fig. 5C; lower right inbox of Fig. 5E; upper left inbox of Fig. 5F; Fig. 8D). Fusules have been used for higher taxonomic classification in "polycystine" Radiolaria, but they are known to vary in structure among species (Anderson 1984). A fusule is a collar structure with a tunnel that is occupied by electrically dense protoplasmic filling termed the inner osmiophilic zone (IOZ in Figs. 7B, D-H, 8D) or outer osmiophilic zone (OOZ in Figs. 7B, D-H, 8D), and is pierced with bundles of microtubuline (Mt in Figs. 7A-H, 8D) in the "polycystine" Radiolaria. The outer diameter and length of a fusule is $0.2-0.5 \mu \mathrm{m}$ and $0.5-1.0 \mu \mathrm{m}$, respectively (Swanberg \& Anderson 1981, Anderson \& Botfield 1983, Sugiyama \& Anderson 1998a, Anderson et al. 1999). Fusules cannot be 
observed with light-transmission microscopy. This general fusule structure is common among "polycystine" Radiolaria, but Collodaria has unique fusules in which the axopodial axoneme is disconnected from the internal axoneme; instead, a rheoplasmic canal extends below the fusule (upper inbox of Fig. 7B) (Anderson et al. 1999). Cyrtid Nassellaria have a similar fusule construction, as shown in Fig. 8D, and the fusule is relatively large (width, 0.5-2.0 $\mu \mathrm{m}$; length, 1.0-1.6 $\mu \mathrm{m}$ ) (Sugiyama \& Anderson 1997, 1998b). Cyrtid Nassellaria are characterized by the presence of porochora (Fig. 8), which appear under light-transmitted microscopy as a pore field (PF in Fig. 8A-C) with closely spaced pores coming from the fusules. In cyrtid Nassellaria, microtubules of $1 \mu \mathrm{m}$ in diameter lie in a fusule at intervals of approximately $0.12 \mu \mathrm{m}$. The acantharian "fusule" is exceptionally simple represented by a tubelike protoplasm that surrounds bundles of axonemes (upper right inbox of Fig. 7A). The fusule structure of Spumellaria is specific to the different axopodial systems (upper inbox of Fig. 7D, G; lower right inbox of Fig. 7D; upper left inbox of Fig. 7F).

Narrow slits or fissures (ca. $50 \mathrm{~nm}$ in width) are found in the solitary Collodaria (Thalassicolla nucleata) (SI in Fig. 5B) (Anderson \& Botfield 1983) and cyrtid Nassellaria (Eucyrtidium hexagonatum Haeckel) (Sugiyama \& Anderson 1997), but are not recognized in the Spumellaria $(H$. amphisiphon) (Anderson et al. 1998).

\section{Pseudopodia and axopodial system}

The pseudopodia of Radiolaria are well known as axopodia and contain significant numbers of microtubuline bundles (e.g. Cachon \& Cachon 1972a, b), but not all the pseudopodia are axopodia. The pseudopodial system is so complex that the definitions and terms are summarized in Table 3. Axopodia (Ax in Figs. 6A, B, 7B-H), axoflagella (Af in Fig. 4M, 7E, F), filopodia (Fp in Fig. 6B), projections (AJ, Ccp, Cvp, P, VP, XP in Figs. 5N, P, 6D), reticulopodia networks ( $\mathrm{RN}$ in Figs. 6C, 7B), and other pseudopodia are recognized in Radiolaria (Figs. 5, 7) on the basis of their cytological structure. The axopodia of Radiolaria, except for those of Collodaria (Fig. 7B), are connected with the intracapsular axopodial system through fusules (Ax in Fig. 7C-H, 8A-C). The term "projection" is only applied for characteristic nassellarian pseudopodia that emerge from particular parts of nassellarian tests (Matsuoka 2007, Sugiyama et al. 2008).

Intracapsular axopodial system (Figs. 7, 8): In contrast to simple radiating axopodia, the intracapsular axopodial system inside the protoplasm exhibits characteristic distribution patterns. This intracapsular axopodial system is comprised of microtubuline bundles of axopodial filaments (AF in Figs. 6B, D, 7A, C-H, 8A-C), axoflagellar filaments (AM in Fig. 7E, F), and axoplasts (Ap in Figs. 6D, 7E, F, H, $8 \mathrm{~A}-\mathrm{C}$ ). The axoplast (Ap in Figs. 6D, 7E, F, H, 8A-C) is a fine fibrillar mass that may enable microtubules to extend the axoneme of axopodia through fusules (Anderson 1977, 1983). The intracapsular axopodial system is situated within the ER as determined from TEM images, although the proximal part of the intracapsular axopodial system appears to be within or projecting out of the nucleus in Acantharia (upper left of Fig. 7A) (Febvre et al. 2000), Spumellaria (lower left of Fig. 7E, F) (Cachon \& Cachon 1972a, b), Nassellaria (Figs. 6D, 8A-C) (Cachon \& Cachon 1971, Sugiyama \& Anderson, 1997, 1998b), and Taxopodia (lower inbox of Fig. 7C) (Cachon \& Cachon 1978). The microtubuline bundles in the axopodia are connected with the axopodial system, but it is unknown whether the protoplasmic part of the axopodia is derived from endoplasm or ectoplasm (Figs. 7, 8). The intracapsular axopodial system is recognized in Spumellaria (Fig. 7E, F), spyrid Nassellaria (Fig. 7G, H), and cyrtid Nassellaria (Fig. 8A-C).

On the basis of the relationship between the axoplast (Ap in Fig. 7) and the nucleus ( $\mathrm{N}$ in Fig. 7), spherical Radiolaria are divided into three groups: "cryptoaxoplastid" (=anaxoplastid) (Fig. 7D), "centroaxoplastid" (Fig. 7E), and "periaxoplastid" (Fig. 7F) (Hollande \& Enjumet 1960, Cachon \& Cachon 1972a, b). Collodaria are also spherical Radiolaria but lack an intracapsular axopodial system, which is called an "exo-axoplastid" (Fig. 7B) (Cachon \& Cachon 1976a). The pattern of the intracapsular axopodial system has been considered as a key character in the higher taxonomic classification of spherical "polycystines" (Hollande \& Enjumet 1960, Anderson 1983, Cachon \& Cachon 1985), but the axopodial system is not concordant with the classification of Spumellaria and their molecular phylogeny (Yuasa et al. 2009).

The axopodial system of Nassellaria varies between Spyrida (Fig. 7G, H) (Sugiyama \& Anderson 1998b) and Cyrtida (Fig. 8A-C) (Sugiyama \& Anderson 1997). Furthermore, Spyrida have a different axopodial system even within the same family. For instance, L. reticulus and $A$. vinculata belong to the family Acanthodesmidae, but the former has an axopodial system with a cryptoaxoplastid (Fig. 7D) or exo-axoplastid structure (Fig. 7B), whereas the latter's system (Fig. 7H) is similar to the periaxoplastid type (Fig. 7F). Cachon \& Cachon (1985) regarded both "cryptoaxoplastid" (Fig. 7D) and "periaxoplastid" (Fig. 7F) as order-level characters but failed to apply them in their classification of the Nassellaria. Sugiyama \& Anderson (1998b) noted that the nucleus-axoplast relationship can be the same among even phylogenetically independent lineages.

In Cyrtida (E. hexagonatum, Spirocyrtis scalaris Haeckel, and Pterocorys zancleus Müller), the axoplast is positioned above the median bar $(\boldsymbol{M B})$ of the internal spicular systems (Figs. 5D, 7A-C) (Cachon \& Cachon 1971, Sugiyama \& Anderson 1997). The axoplast of Cyrtida is periaxoplastid (Fig. 7F). Significant axopodial filaments (AF in Fig. 8A-C) tend to extend diversely into the center of the conical siliceous test and probably connect with terminal projections (TP in Fig. 6D, TP and AF in Fig. 8A-C). The axopodial filament (AF in Fig. 8A-C) was recognized 
in Cyrtida as early as the late 19th century as a cone-shaped organelle (e.g. Hertwig 1879), now called a podoconus (PN in Fig. 7).

Pseudopodia: The cytoskeleton of the radiolarian axopodia has been well studied in the context of higher taxonomic classifications in the "Actinopoda," ever since symmetrically arranged axoneme bundles were first recognized in Heliozoa (Actinophrys and Actinosphaerium) (Eagles 1967). A unit of an axoneme bundle consists of six hexagonally arranged axonemes, and these hexagonal bundles are connected to each other. The internal axopodial structure has been described in a variety of radiolarian groups, and these studies all assume that the axopodial structure reflects higher classification; however, this assumption has received little attention in subsequent taxonomic studies.

Acantharia have three types of pseudopodia; axopodia (Ax in Fig. 6A), the pseudopodia from the tip of acantharian spicules (Ps in Fig. 6A), and pseudopodial filaments (not shown). Acantharian axopodia are more or less invisible (Fig. 4C-H), presumably due to there being fewer axoneme bundles in the axopodia (Febvre et al. 2000). Acantharia lack an intracapsular axopodial system (Fig. 7A). Instead, bundles of microtubules (Mt in Fig. 7A) attach directly to the perispicular membrane (PM in Fig. 7A) that envelopes the central region of the acantharian spicules (Mt and PM in Fig. 6A). Microtubules simply pierce through the capsular wall to form axopodia (upper right inbox of Fig. 7A) (Febvre et al. 2000); thus, the acantharian axopodia are part of the endoplasm (Ax and Mt in Fig. 6A). Acantharian spicules extend the pseudopodia (Ps in Fig. $6 \mathrm{~A})$, which are connected with the myoneme ( $\mathrm{M}$ in Fig. 6A). The myoneme consists of bundles of retractable fibrillar cytoskeletons and is a unique motile protoplasmic structure in Acantharia (Febvre 1971, 1974, 1981).

Spumellaria have axopodia (Ax in Fig. 6B), filopodia (Fp in Fig. 6B), and an axoflagellum (Af in Fig. 4K, M) (Hollande \& Enjumet 1960, Cachon \& Cachon 1972a, b). The axopodia consist of microtubules, vacuoles, mitochondria, and protoplasmic reticulum within the protoplasm (Anderson 1976b). Food inclusion has never been observed along or within the axopodia, therefore it is concluded that phagocytosis mainly occurs on or in the ectoplasm (Cachon \& Cachon 1976b). Some axopodia also contain a rather granular protoplasmic matrix ( $\mathrm{cpl}$ in Fig. 4B, J, P). The axoflagellum (Af in Figs. 4K, M, 7E, F) is a significantly thick and longer pseudopodia. In most cases, if an axoflagellum is present in a cell, it is a single axoflagellum. Filopodia (Fp in Fig. 6B) are a slender extension of the ectoplasm. Pseudopodia also extend from the tip of radial spines and other spiny structures (De Wever et al. 1994, Suzuki 2005), but their physiological functions are unknown.

Bundles of microtubules (Mt in Fig. 7B) are recognized in the pseudopodia of solitary Collodaria (Thalassolampe and Thalassicolla) (Cachon \& Cachon 1976a, 1977), whereas microtubules never extend into the pseudopodia of colonial Collodaria (Sphaerozoum and Collozoum) (Ander- son 1976a, c). Instead of axopodia, colonial Collodaria develop a reticulopodial network ( $\mathrm{RN}$ in Fig. 6C). Colonial Collodaria occasionally possess large bubble-like alveoli in the extracapsulum (BA in Figs. 5F, 6C), and these bubblelike alveoli are generally attached to the reticulopodial network near the mitochondria (Mc in Fig. 6C) (Anderson 1976a, b, c), suggesting some biological functions for these alveoli.

Cyrtid Nassellaria radiate many pseudopodia, called projections (Matsuoka 2007, Sugiyama et al. 2008) (AJ, Ccp, CvP, CZ, TP, VP, XP in Figs. 5N-P, 6D) but the cytoskeleton of these projections is poorly understood. The projections (apical, dorsal, primary lateral, or ventral) extend from the cephalis (AJ and VP in Figs. 5N, P, 6B) and are likely related to initial spicular systems and other cephalic structures. The axial projection (XP in Figs. 5P, 6D, 8A, B) is a single thick pseudopodium from the aperture, similar to the axoflagellum of Spumellaria, and cyrtid nassellarians use the axial projection for capturing prey (Sugiyama et al. 2008). The terminal projections (TP in Figs. 5P, 6D, 8A, B) are the fine pseudopodia that radiate from the aperture. They often form a terminal cone (TC in Figs. 6D, 8A, B). The projections extending from concavities between segments are "projections from concavities" (Ccp in Figs. 5N, 6D) whereas those from a convex part of the test such as the middle part of a barrel-shaped segment are "projections from convexities" (CvP in Figs. 5N, P, 6D).

Spyrid Nassellaria also radiate numerous pseudopodia throughout a cell, but most are presumed to be non-axoneme pseudopodia (Ps in Fig. 5J, K). Sugiyama \& Anderson (1998b) have shown that there are few fusules connected with the axoneme bundles of the axopodia, in contrast with the huge number of pseudopodia.

The axopodia of Taxopodia have been well studied because of their interesting oar-like movement (Oar in Fig. 4R-U) (e.g. Cachon et al. 1977, Cachon \& Cachon 1978). Sticholonche zanclea has axopodia that are on average $150 \mu \mathrm{m}$ long, and that can be classified as dorsal axopodia $(\mathrm{Ax}(\mathrm{D})$ in Fig. 7C), dorsolateral axopodia $(\mathrm{Ax}(\mathrm{Dl})$ in Fig. 7C), lateral axopodia ( $\mathrm{Ax}(\mathrm{l})$ in Fig. 7C), and ventral axopodia $(\mathrm{Ax}(\mathrm{V})$ in Fig. $7 \mathrm{C})$ on the basis of their location. Dorsal axopodia (Ax(D) in Fig. 7C) are arranged into two halves by a central dorsal midline space, where approximately 160 axopodia are present. The axopodia on the anterior side of the cell are larger than those on the posterior side. The taxopod axopodia differ from those in other Radiolaria in that they arise from the nuclear capsule instead of the capsular wall (lower inbox of Fig. 7C). The axopodial root is concave on the nuclear membrane surface and appears as a lattice pattern under light transmission microscopy. The dense axopodial head lies on the surface of the nuclear membrane with strands of microfilaments (Mf in Fig. 7C). Axopodia are connected with joint filaments ( $\mathrm{Aj}$ in Fig. $7 \mathrm{C}$ ) that probably control their simultaneous movement. These microfilaments and fibrils are not composed of actin, because of their size and structure. Axopodia can move by means of 
contractile microfilaments under calcium control.

\section{Extracapsulum}

The ectoplasm (Ect in Fig. 6A-D), cytokalymma (Ct in Fig. 6A-H, 8D), gelatinous matrix (GM in Figs. 5D-I, 6D), periplasmic cortex ( $\mathrm{PC}$ in Figs. 4D, G, H, 6A), and pseudopodia (Ps in Figs. 4J, K, P, 5E, J, K, 6A) are recognized as extracapsular organelles of the extracapsulum (Ext in Figs. 4B-D, F-H, J, 5E, 6B, C), but the relationships between the ectoplasmic membrane, axopodial membrane, and cytokalymma is not fully understood. The ectoplasm is the outer protoplasm surrounding the capsular wall, and the cytokalymma is a protoplasmic sheath enveloping the axopodial reticulum (Ct in Figs. 6A-H, 8D). The gelatinous matrix (GM in Figs. 5D-I, 6D) is named for the colonial gelatin of colonial Collodaria, and the periplasmic cortex ( $\mathrm{PC}$ in Figs. 4D, G, H, 6A) is the tent-like plasmalemma of Acantharia. The density and size of extracapsular mitochondria in Thalassicolla nucleata are 10 mitochondria 100 $\mu \mathrm{m}^{-2}$ and $0.92 \mu \mathrm{m}$ in length, whereas those in the intracapsulum are 26 mitochondria $100 \mu \mathrm{m}^{-2}$ and $1.4 \mu \mathrm{m}$ in length, respectively.

Ectoplasm: The ectoplasm of Spumellaria (Ect in Fig. 6B), Nassellaria (Ect in Fig. 6D), and solitary Collodaria (Ect in Fig. 5E) is generally alveolated, transparent, or slightly milky in color and contains ectoplasmic reticulum, digestive vacuoles (DV in Figs. 5B, 6C) or waste vacuoles (WV in Fig. 6D), perialgal vacuoles (PV in Fig. 6B), and filopodia (Fp in Fig. 6B). As early as the late 19th century, Haeckel (1887) presumed the extracapsulum to be a major site of catabolism, and this hypothesis has since been supported by biochemical studies (e.g. Anderson \& Botfield 1983). Acid aryl phosphatase, a marker enzyme for digestive activity, has been detected in the extracapsulum of a solitary collodarian (Thalassicolla sp.) (Anderson 1984). The volume of ectoplasm changes significantly even within the same cell, depending on conditions (Suzuki 2005) and after predation (Suzuki \& Sugiyama 2001), which can be explained by acquisition of food in the ectoplasm.

The alveolate ectoplasm is recognized mainly within the innermost ectoplasm. Food vacuoles (DV in Fig. 6B) have been examined by TEM, and diatoms, dinoflagellates, nonthecate algae, and microheterotrophs were found in the spumellarian D. tetrathalamus (Anderson et al. 1990, Sugiyama \& Anderson 1998a). Larger Radiolaria (Anderson 1978a, 1983, Anderson et al. 1984) contain metazoan prey (such as segments of muscle, adipose tissue, or clumps of cells) in their food vacuoles.

Organelle composition in the ectoplasm is similar among Spumellaria, solitary Collodaria, and Nassellaria, but cyrtid Nassellaria have eccentrically located organelles. The extracapsulum of cyrtid Nassellaria is highly alveolated, mainly below the protoplasmic lobes where numerous waste vacuoles (WP in Fig. 6D) and perialgal vacuoles with algal symbionts are concentrated (Sugiyama \& Anderson 1997).
In Spumellaria (D. tetrathalamus and H. amphisiphon) (Anderson \& Botfield 1983, Sugiyama \& Anderson 1998a), the extracapsular membrane is initially enclosed within the innermost cortical shell. In the grown spumellarian cell, the ectoplasm forms a variety of lobes that project out from the pores of the cortical shells (Hollande \& Enjumet 1960). Haeckel (1862) used the term "exosphere" to describe the taxonomically important structure of concentric shells present outside of the ectoplasm, but it is considered less important now because it is known that the extent and volume of ectoplasm varies significantly.

The extracapsular membrane (EW in Fig. 6D) encloses the siliceous skeleton in the cyrtid Nassellaria. The cyrtid extracapsular membrane differs from that of Spumellaria in that it is composed of small, electron-dense spherules interconnected by fine filamentous strands. This membrane has been called the extracapsular wall by Sugiyama \& Anderson (1997).

Gelatinous matrix: Colonial Collodaria develop a webby reticulopodial network ( $\mathrm{RN}$ in Fig. 6C) throughout the gelatinous colony matrix (GM in Figs. 5B-I, 6B) (Anderson 1976a) and bubble-like alveoli (BA in Figs. 5F, 6C) (Anderson \& Botfield 1983) (Fig. 6C). The reticulopodial network (RN if Fig. 6C) of colonial Collodaria serves the same physiological function as the pseudopodia and ectoplasm of other "polycystine" Radiolaria, and its gelatinous matrix is clearly separated from the reticulopodial network (Swanberg \& Anderson 1981). In contrast to Spumellaria and Nassellaria, food vacuoles, digestive vacuoles, and waste vacuoles occur within the reticulopodial network (DV in Fig. 6C) of colonial Collodaria (Collozoum caudatum), not within the ectoplasm (Swanberg \& Anderson 1981). The gelatinous matrix is secreted from membrane-bound granules (not shown) (Anderson 1976a). The bubble-like alveoli (BA in Fig. 5F) break up when a colonial Collodaria (Sphaerozoum fuscum) is disturbed, suggesting a buoyancy control function (Anderson 1976c). The alveoli are not simply hollow, because mitochondria (Mc in Fig. 6C) are sparsely distributed throughout.

Cytokalymma: The radiolarian skeleton is wrapped within a protoplasmic sheath called the cytokalymma (Anderson 1976a, 1983, Swanberg et al. 1985). A silica-secreted cytokalymma is called the "silikalyomma" (Anderson 1984). Ogane et al. $(2009,2010)$ proved the presence of the silica secretion site (probably silica deposition vacuole: $\mathrm{SV}$ ) on the skeletons of Nassellaria and spheroidal Spumellaria.

Periplasmic cortex: The periplasmic cortex (or ectoplasmic cortex) is a peculiar protoplasmic wall joined with 10 or 20 acantharian spicules (PC in Fig. 6A) (Febvre et al. 2000). It consists of elastic thin fibrils arranged in a checkered hexagonal or polygonal pattern of 20 polygonal pieces that join each other through a junction area (Febvre 1972, 1973). This wall resembles an ectoplasmic membrane but is connected with a perispicular membrane (PM in Fig. 7A) and capsular walls. The protoplasm of Acantharia is en- 
closed by another plasmalemma that is beneath the capsular wall.

A transparent zone is present between the capsular wall (CW in Fig. 6A) and the periplasmic cortex (PC in Fig. 6A), and is considered to be a space occupied by seawater. The periplasmic cortex is a very motile membrane that controls buoyancy by contraction of the myoneme along the acantharian spicules.

Symbionts: Algal symbionts are generally present in the extracapsulum (SY in Fig. 6A-D). Probable symbiotic algae and bacteria are enclosed in the ectoplasm of some radiolarians (e.g. Didymocyrtis tetrathalamus) (Sugiyama \& Anderson 1998a). Perialgal vacuoles (PV in Fig. 6B) contain algal symbionts, but they are clearly separated from the food vacuoles (SY in Fig. 6C) (Swanberg et al. 1985).

\section{Summary}

We have emphasized the differences in cytological structure among the radiolarians. For example, Collodaria have been considered to be a typical example of Spumellaria, but this assumption is not acceptable on the basis of cytological and geological considerations. The historic use of criteria such as the capsular wall and axopodia do not satisfy the current taxonomy either. The long evolutionary history of Radiolaria from Cambrian time permits ample opportunity for both convergence and differentiation in cytological structure. Taxonomic issues can be easily solved by examining living "fossil" species whose geological ranges are well understood. There is also potential with molecular analysis, although such research has yet to be apllied to discriminate classifications at the species and genus levels.

Radiolaria are known for possessing beautiful symmetric skeletal morphologies, as shown in Haeckel (1887). Many plates of Haeckel (1887) have been cited as proof of this symmetry, but it creates a transient and rather misleading impression of perfection for those who are not radiolarian specialists. Almost all specimens illustrated in Haeckel (1887) have failed to be located despite considerable effort. We have visited the Natural History Museum of London and the Haeckel Haus in Jena (Germany), where his original radiolarian slides are allegedly archived, and failed to find such "beautiful" specimens (Aita et al. 2009, Sakai et al. 2009). Only a few original slides are still there and it is presumed that many have been lost or destroyed (Lazarus \& Suzuki 2009). Haeckel (1887) is still an important reference for Radiolaria, but we do not recommend use of his illustrations as exemplary for Radiolaria.

While summarizing the cytology and molecular biological analysis of Radiolaria, we encountered many difficulties and inconsistencies with identification. The taxonomy of "polycystines" has been significantly advanced by micropaleontologists. However, we have had to omit citations in our review if, in our opinion, the identification is indeterminable in terms of the current taxonomic sense. We found several papers in which Acantharia was erroneously identi- fied as Spumellaria, even with the presence of Müller's rule. This misidentification may be attributable in part to the extraordinarily symmetrical images of Haeckel (1887).

Our review presents relatively advanced knowledge on radiolarian cytology. However, the cytological structure of fewer than 25 "polycystine" species, estimated to be only $4 \%$ of the 800 living "polycystine" species, have been examined with electron transmission microscopy. Molecular biological analysis has been conducted for even fewer radiolarian species. Phylogenetic and taxonomic data on "polycystine" Radiolaria has been accumulated from micropaleontological studies but has not yet been fully assimilated into our understanding of Radiolaria. However, Radiolaria are one of the most attractive protistan groups, not only for micropaleontologists but also for biologists and ecologists.

\section{Acknowledgments}

We would like to sincerely thank Susumu Ohtsuka (Hiroshima Univ.), the chief editor of this journal, for inviting us to write a review on Radiolaria. Akihiro Tuji (National Museum of Nature and Science) was also very helpful to us with respect to introductory biological knowledge of protistan groups, because our knowledge is largely micropaleontology-based. Some images of living Radiolaria were photographed by attendants at the Observation Tour of Living Radiolarians at Sesoko Islands, presided over by Atsushi Matsuoka (Niigata Univ.). We are greatly indebted to Yoshikatsu Nakano and the staff of the Sesoko Tropical Biosphere Research Center and the University of the Ryukyus for their generous hospitality and assistance with sampling. Several living radiolarian images were also taken during the 2008-04 cruise of the TRV Toyoshio-Maru (Hiroshima Univ.). Captain Akio Go and the crew of the TRV Toyoshio-Maru provided us with many opportunities to collect numerous valuable samples. The manuscript was greatly improved by the constructive comments of two reviewers, Hamish Campbell and Atsushi Matsuoka. In particular, we gratefully acknowledge Campbell for revising much of our manuscript.

\section{References}

Adl SM, Simpson GB, Farmer MA, Andersen RA, Anderson OR, Barta JR, Bowser SS, Brugerolle G, Fensome RA, Fredericq S, James TY, Karpov S, Kugrens P, Krug J, Lane CE, Lewis LA, Lodge J, Lynn DH, Mann DG, Mccourt RM, Mendoza L, Moestrup Ø, Mozley-Standridge SE, Nerad TA, Shearer CA, Smirnov AV, Spiegel FW, Taylor MFJR (2005) The new higher level classification of Eukaryotes with emphasis on the taxonomy of Protists. J Eukaryot Microbiol 52: 399-451.

Afanasieva MS, Amon EO (2006) Radiolaria. Russian Academy of Sciences, Paleontological Institute, Institute of Geology and Geochemistry, PIN RAS, Moscow, 320 pp. (in Russian)

Aita Y, Suzuki N, Ogane K, Sakai T, Lazarus D, Young J, Tanimura Y (2009) Haeckel Radiolaria Collection and the H.M.S. 
Challenger plankton collections. Nat Mus Natl Sci Monogr 40: $35-45$.

Anderson OR (1976a) Ultrastructure of a colonial radiolarian Collozoum inerme and a cytochemical determination of the role of its zooxanthellae. Tiss Cell 8: 195-208.

Anderson OR (1976b) A cytoplasmic fine-structure study of two spumellarian Radiolaria and their symbionts. Mar Micropalentol 1: 81-99.

Anderson OR (1976c) Fine structure of a collodarian radiolarian (Sphaerozoum punctatum Müller 1858) and cytoplasmic changes during reproduction. Mar Micropaleontol 1: 287-297.

Anderson OR (1977) Cytoplasmic fine structure of nassellarian Radiolaria. Mar Micropaleontol 2: 251-264.

Anderson OR (1978a) Light and electron microscopic observations of feeding behavior, nutrition, and reproduction in laboratory cultures of Thalassicolla nucleata. Tiss Cell 10: 401-412.

Anderson OR (1978b) Fine structure of a symbiont-bearing colonial radiolarian, Collosphaera globularis, and ${ }^{14} \mathrm{C}$ isotopic evidence for assimilation of organic substances from its zooxanthellae. J Ultrast Res 62: 181-189.

Anderson OR (1983) Radiolaria. Springer-Verlag, New York, 355 pp.

Anderson OR (1984) Cellular specialization and reproduction in planktonic foraminifera and Radiolaria. In: Marine Plankton Life Cycle Strategies (eds Steidinger K, Walker L). Chemical Rubber Co. Press, pp. 36-66.

Anderson OR, Botfield M (1983) Biochemical and fine structure evidence for cellular specialization in a large spumellarian radiolarian, Thalassicolla nucleata. Mar Biol 72: 235-241.

Anderson OR, Bryan M, Bennett P (1990) Experimental and observational studies of radiolarian physiological ecology: 4. Factors determining the distribution and survival of Didymocyrtis tetrathalamus tetrathalamus with implication for paleoecological interpretations. Mar Micropaleontol 16: 155-167.

Anderson OR, Danelian T, Langdon C (1998) Cytoplasmic and shell fine structure of Tetrapetalon elegans (Polycystinea) and comparisons to Hexacontium spp. with implications for phylogeny and taxonomy of the Spumellarida. Mar Micropaleontol 33: 299-307.

Anderson OR, Gastrich MD, Amaral-Zettler LA (1999) Fine structure of the colonial radiolarian Collozoum serpentinum (Polycystinea: Spumellaria) with a reconsideration of its taxonomic status and re-establishment of the genus Collophidium (Haeckel). Micropaleontology 36: 81-89.

Anderson OR, Swanberg NR, Bennett P (1984) An estimation of predation rate and relative preference for algal versus crustacean prey by a spongiose skeletal radiolarian. Mar Biol 78: 205-207.

Bernstein RE, Kling SK, Boltovskoy D (1999) Acantharia. In: South Atlantic Zooplankton (ed Boltovskoy D). Backhuys Publishers, Leiden, pp. 75-147.

Bernstein T (1934) Zooplankton des nördlichen Teiles des Karischen Meeres. Trans Arct Inst 9: 3-58.

Boltovskoy D (1999) Radiolaria Polycystina. In: South Atlantic Zooplankton (ed Boltovskoy D). Backhuys Publishers, Leiden, pp. 149-212.

Brandt K (1885) Die koloniebilden Radiolarien (Sphaerozoeen) des Golfes von Neapel. Fauna Flora Golfes Neapel 13: 1-276.
Brandt K (1905) Zur Systematik der kolonienbildenden Radiolaria. Z Jahrb, Suppl 8: 311-352.

Cachon J, Cachon M (1971) Le système axopodial des Radiolaries Nassellaires. Arch Protistenkd 113: 80-97.

Cachon J, Cachon M (1972a) Le système axopodial des Radiolaires Sphaeroïdés. I. Centroaxoplastidiés. Arch Protistenkd 114: 51-64.

Cachon J, Cachon M (1972b) Le système axopodial des Radiolaires Sphaeroidés. II. Les Périaxoplastidiés, III. Les Cryptoaxoplastidiés (Anaxopastidiés), IV. Les fusules et le système rhéoplasmique. Arch Protistenkd 114: 291-307.

Cachon J, Cachon M (1976a) Le Système axopodial des Collodaires (Radiolaires Polycystines) 1. Les Exo-axoplastidíes. Arch Protistenkd 118: 227-234.

Cachon J, Cachon M (1976b) Les axopodes de Radiolaires dans leur partie libre et ectoplasmique. Structure et fonction. Arch Protistenkd 118: 310-320.

Cachon J, Cachon M (1977) Le système axopodial des Colladaires (Radiolaires Polycystines). 2. Thalassolampe margarodes Haeckel. Arch Protistenkd 119: 401-406.

Cachon J, Cachon M (1978) Sticholonche zanclea Hertwig: A reinterpretation of its phylogenetic position based upon new observations on its ultrastructure. Arch Protistenkd 120: 148-168.

Cachon J, Cachon M (1985) 2. Class Polycystinea. In: Illustrated Guide to the Protozoa (eds Lee JJ, Hutner SH, Bovee EC). Society of Protozoologists, Lawrence, Kansas, pp. 283-295.

Cachon J, Cachon M, Tilney LG, Tilney MS (1977) Movement generated by interactions between the dense material at the ends of microtubules and non-actin-containing microfilaments in Sticholonche zanclea. J Cell Biol 72: 314-338.

Calkins G (1909) Protozoölogy. Lea \& Febiger, New York, 349 pp.

Campbell AS (1954) Radiolaria. In: Treatise on Invertebrate Paleontology, Part D Protista 3. Protozoa (Chiefly Radiolaria and Tintinnina) (ed Moore RC). Geological Society of America and University of Kansas Press, Kansas, pp. D1-D163.

Cavalier-Smith T, Chao EEY (2003) Molecular phylogeny of centrohelid Heliozoa, a novel lineage of Bikont Eukaryotes that arose by ciliary loss. J Mol Evol 56: 387-396.

Cheng YN (1986) Taxonomic studies on Upper Paleozoic Radiolaria. Nat Mus Nat Sci, Spec Publ 1: 1-213.

De Wever P, Azéma J, Fourcade E (1994) Radiolaires et radiolarites: production primaire, diagenèse et paléogéographie. Bull Cent Rech Explor Prod Elf-Aquitaine 18: 315-379.

De Wever P, Dumitrica P, Caulet JP, Nigrini C, Caridroit M (2001) Radiolarians in the Sedimentary Record. Gordon and Breach Science Publishers, Amsterdam, 533 pp.

Dumitrica P (1984) Sistematika radiolyariy Sphaerellaria. In: Morfologiya, Ekologiya i Evolyutsiya Radiolyariyi (eds Petrushevskaya MG, Stepyan'yand SD). Nauka, Leningrad, pp. 91102. (in Russian)

Eagles CF (1967) Axopodial filaments of Heliozoa. Nature 215: 99-101.

Febvre J (1971) Le myoneme d'Acantaire: Essai d'interprétation ultrastructurale et cinétique. Protistologica 7: 379-381.

Febvre J (1972) Le cortex ectoplasmique des acanthaires I. Les systemes mailles. Protistologica 8: 169-178.

Febvre J (1973) Le cortex des Acanthaires II. Ultrastructure des 
zones de jonction entre les pieces corticales. Protistologica 9: 87-94.

Febvre J (1974) Relations morphologiques entre les constituants de l'enveloppe, les myonemes, le squelette et le plasmalemme chez les Arthracantha Schew (Acantharia). Protistologica 10: 141-158.

Febvre J (1977) La division nucléaire chez les Acanthaires 1. Étude ultrastructurale de la mitose, comparaion avec la caryocinèse d'autres organismes. J Ultrastr Res 60: 279-295.

Febvre J (1981) The myoneme of the Acantharia (Protozoa): A new model of cellular motility. Biosystems 14: 327-336.

Febvre C, Febvre J, Michaels A (2000) Acantharia Haeckel, 1881. In: An Illustrated Guide to the Protozoa (2nd edition). Organisms Traditionally Referred to As Protozoa, or Newly Discovered Groups (eds Lee JJ, Leedale GF, Bradbury P). Society of Protozoologists, Lawrence, Kansas, pp. 783-803.

Febvre J, Febvre-Chevalier C (1982) Motility processes in Acantharia (Protozoa). I. Cinematographic and cytological study of the myonemes. Evidence for a helix-coiled mechanisms of the constituent filaments. Biol Cell 44: 283-304.

Fol H (1883) Sur le Sticholonche zanclea et un nouvel ordre de Rhizopodes. Mem Inst Nat Genevois 15: 1-35.

Haeckel E (1862) Die Radiolarien (Rhizopoda Radiolaria). Eine Monographie. Tafel 1. Reimer, Berlin, 572 pp.

Haeckel E (1882) Entwurf eines Radiolarien-Systems auf Grund von Studien der Challenger-Radiolarien. Jena $Z$ Natwiss mednatwiss Ges Jena 15: 418-472.

Haeckel E (1887) Report on the Radiolaria collected by H.M.S. Challenger during the years 1873-1876. Rep Sci Res Voyage H.M.S. Challenger, Zoology 18: 1-1803.

Hertwig R (1879) Der Organismus der Radiolarien. Verlag von Gustav Fischer, Jena, 149 pp.

Hollande A, Cachon J, Cachon M, Valentin J (1967) Infrastructure des axopodes et organisation générale de Sticholonche zanclea Hertwig (Radiolaire Sticholonchidea). Protistologica 3: 155166.

Hollande A, Enjumet M (1960) Cytologie, évolution et systématique des Sphaeroïdés (Radiolaires). Arch Mus Natl Hist Nat, 7 7: 1-134.

Hollande A, Martoja R (1974) Identification du Cristalloide des isospores de radiolaires a un cristal de célestite $\left(\mathrm{SrSO}_{4}\right)$ détermination de la constitution du cristalloide par voie cytochimique et a l'aide de la microsonde électronique et du microanalyseur par émission ionique secondaire. Protistologica 10: 603609.

Huth W (1913) Zur Entwiklungsgeschichte der Thalassicollen. Arch Protistenkd 30: 1-124.

Integrated Ocean Drilling Program (2007) About IODP. Available at: http://www.iodp.org/about/ (access on 1 August 2010)

Itaki T (2005) Introduction to radiolarian study. Fossils 77: 45-50. (in Japanese with English abstract)

Kobayashi T, Kimura T (1944) A study on the radiolarian rocks. J Fac Sci Imperial Univ Tokyo 27: 75-178.

Kozur H, Mostler H (1972) Beiträge zur Erforschung der mesozoischen Radiolarien. Teil I: Revision der Oberfamilie Coccodiscacea Haeckel 1862 emend. und Beschreibung ihrer triassischen Vertreter. Geol-Paläontol Mitt Innsbruck 2: 1-60.

Kozur H, Mostler H (1978) Beiträge zur Erforschung der meso- zoischen Radiolarien. Teil II: Oberfamilie Trematodiscacea Haeckel 1862 emend. und Beschreibung ihrer triassischen Vertreter. Geol-Paläontol Mitt Innsbruck 8: 123-182.

Kozur H, Mostler H (1979) Beiträge zur Erforschung der mesozoischen Radiolarien. Teil III: Die Oberfamilien Actinommacea Haeckel 1862 emend., Artiscacea Heackel 1882, Multiarcusellacea nov. der Spumellaria und triassische Nassellaria. GeolPaläontol Mitt Innsbruck 9: 1-132.

Kozur H, Mostler H (1982) Entactinaria subordo nov., a new radiolarian suborder. Geol-Paläontol Mitt Innsbruck 11/12: 399414.

Kunitomo Y, Sarashina I, Iijima M, Endo K, Sashida K (2006) Molecular phylogeny of acantharian and polycystine radiolarians based on ribosomal DNA sequences, and some comparisons with data from the fossil record. Euro J Protistol 43: 143-153.

Lazarus D (2005) A brief review of radiolarian research. Paläontol Z 79: 183-200.

Lazarus D, Suzuki N (2009) Introduction to the reexamination of the Haeckel and Ehrenberg radiolarian collections. Nat Mus Natur Sci Monogr 40: 23-34.

Lee JJ, Leedale GF, Bradbury P (2000) An Illustrated Guide to the Protozoa, Second edition. Society of Protozoologists, Lawrence, Kansas, 1432 pp.

Matsuoka A (2007) Living radiolarian feeding mechanisms: new light on past marine ecosystems. Swiss J Geosci 100: 273-279.

Meunier A (1910) Microplankton des Mer de Barents et de Kara. Duc d'Orléans, Campagne Arctique de 1907. Imprimerie Scientifique, Bruxelles, 255 pp.

Meyen FJF (1834) Beiträge zur Zoologie: gesammelt auf einer Reise um die Erde. Fünfte Abhandlung von F.J.F. Meyen. Über das Leuchten des Meeres und Beschreibung einiger Polypen und anderer niederer Thiere. Verh Kaiser Leopld-Carolin Akad Natforsch 16 (suppl 1): 125-216.

Müller J (1858) Über die Thalassicollen, Polycystinen und Acanthometren des Mittelmeeres. Abh König Akad Wiss Berlin 1858: $1-62$.

Network of Osaka Micropaleontologists (NOM) (2007) Radiolarian reference database. Available at: http://homepage3.nifty. com/radiolarians/ (accessed on 1st August 2010)

Ogane K, Suzuki N (2006) Morphological terms describing discoidal radiolarians. Rev Micropal 49: 97-104.

Ogane K, Tuji A, Suzuki N, Kurihara T, Matsuoka A (2009) First application of PDMPO to examine silicification in polycystine Radiolaria. Plankton Benthos Res 4: 89-94.

Ogane K, Tuji A, Suzuki N, Matsuoka A, Kurihara T, Hori RS (2010) Direct observation of the skeletal growth patterns of polycystine radiolarians using a fluorescent marker. Mar Micropaleontol 77: 137-144.

Oka A, Endo K, Sashida K (2005) Molecular phylogeny of Acantharea (Actinopodea: Protista) based on small subunit rRNA gene sequences. Sci Rep Inst Geosci Univ Tsukuba, B 26: 13-22.

Pawlowski J, Burki F (2009) Untangling the phylogeny of amoeboid Protists. J Eukaryot Microbiol 56: 16-25.

Petrushevskaya MG (1971) Radiolyarii Nasselaria v planktone Mirovogo okeana. Tr Zool Inst, Akad Nauk, SSSR 9: 1-294. (in Russian)

Petrushevskaya MG (1981) Radiolyarii Otryada Nasselaria 
Mirovogo Okeana. Akad Nauk SSSR, Zool Inst 128: 1-405. (in Russian)

Petrushevskaya MG (1984a) Terminyi, Yporebkyaemyie pri Opisanii Skeletov Radiolyariy. VSEGEI, 72 pp. (in Russian)

Petrushevskaya MG (1984b) O kalssifikatsii radiolyariy Polycystina. In: Petrushevskaya MG, Stepyan'yand SD, (eds.) Morfologiya, Ekologiya i Evolyutsiya Radiolyariyi, Nauka, Leningrad, pp. 124-148. (in Russian)

Petrushevskaya MG (1986) Radiolyarievyy Analiz. Akad Nauk SSSR, Zool Inst, Nauka. Leningrad, 1-199 pp. (in Russian)

Poche F (1913) Das System der Protozoa. Arch Protistenkd 30: 125-321.

Reshetnyak VV (1981) Akantarii (Acantharia, Protozoa) Mirovogo okeana. Fauna SSSR 123: 1-224. (in Russian)

Sakai T, Suzuki N, Ogane K, Lazarus D, Breidbach O, Bach T (2009) Haeckel's Messina radiolarian collection in the ErnstHaeckel-Haus. Nat Mus Natl Sci Monogr 40: 47-54.

Sanfilippo A, Westberg-Smith MJ, Riedel WR (1985) Cenozoic Radiolaria. In: Bolli HM, Saunders JB, Perch-Nielsen K, (eds.) Plankton Stratigraphy, Cambridge University Press, Cambridge, pp. 631-712.

Schewiakoff W (1926) Die Acantharien des Golfes von Neapel. Fauna Flora Golfes Neapel 37: 1-755.

Stiasny G (1908) Einige Beobachtungen über Sticholonche zanclea Hertwig. Zool Anz 33: 440-445.

Strelkov AA, Reshetnyak VV (1971) Kolonialnye radiolyarii Spumellaria Mikrovogo Okeana. Issl Fauna Mor 9: 295-418. (in Russian)

Sugiyama K, Anderson OR (1997) Correlated fine structural and light microscopic analyses of living nassellarians Eucyrtidium hexagonatum Haeckel, Pterocorys zancleus (Müller) and Spirocyrtis scalaris Haeckel. NOM, Spec Vol 10: 311-337.

Sugiyama K, Anderson OR (1998a) Cytoplasmic organization and symbiotic associations of Didymocyrtis tetrathalamus (Haeckel) (Spumellaria, Radiolaria). Micropaleontology 44: 277-289.

Sugiyama K, Anderson OR (1998b) The fine structures of some living Spyrida (Nassellaria, Radiolaria) and their implications for nassellarian classification. Paleontol Res 2: 75-88.

Sugiyama K, Hori RS, Kusunoki Y, Matsuoka A (2008) Pseudopodial features and feeding behavior of living nassellarians Eucyrtidium hexagonatum Haeckel, Pterocorys zancleus (Müller) and Dictyocodon prometheus Haeckel. Paleontol Res 12: 209-222.

Suzuki N (1998) Morphological terminology of spheroidal Polycystine (Radiolaria). NOM, Spec Vol 11: 251-287. (in Japanese with English abstract)

Suzuki N (2005) Physiological axopodial activity of Rhizosphaera trigonacantha Haeckel (a spheroidal radiolarian, Polycystina, Protista). Mar Micropaleontol 54: 141-153.

Suzuki N (2006) Ontogenetic growth and variation in the skeletal structure of two Late Neogene Sphaeropyle species (Polycystina radiolarians). J Paleontol 80: 849-866.

Suzuki N, Aita Y (2011) Topics on the spatial distribution, standing stocks, and symbiosis of living Radiolaria (Rhizaria, Pro- toctista). Bull Plankton Soc Japan 58: 19-27 (in Japanese with abstract)

Suzuki N, Ogane K, Chiba K (2009a) Middle to Eocene polycystine radiolarians from the Site 1172, Leg 189, Southwest Pacific. NOM, Spec Vol 14: 239-296.

Suzuki N, Ogane K, Aita Y, Kato M, Sakai S, Kurihara T, Matsuoka A, Ohtsuka S, Go A, Nakaguchi K, Yamaguchi S, Takahashi T, Tuji A (2009b) Distribution patterns of the radiolarian nuclei and symbionts using DAPI-fluorescence. Bull Natl Mus Nat Sci B 35: 169-182.

Suzuki N, Sugiyama K (2001) Regular axopodial activity of Diplosphaera hexagonalis Haeckel (spheroidal spumellarian, Radiolaria). Paleontol Res 5: 131-140.

Swanberg NR (1983) The trophic role of colonial Radiolaria in oligotrophic oceanic environments. Limnol Oceanogr 28: 655-666.

Swanberg NR, Anderson OR (1981) Collozoum caudatum sp. nov: A giant colonial radiolarian from equatorial and Gulf Stream waters. Deep-Sea Res Part A 28: 1033-1047.

Swanberg NR, Anderson OR, Bennett P (1985) Spongiose spumellarian Radiolaria: The functional morphology of the radiolarian skeleton with a description of Spongostaurus, a new genus. Mar Micropaleontol 9: 455-464.

Swanberg NR, Anderson OR, Bennett P (1990) Skeletal and cytoplasmic variability of large spongiose spumellarian Radiolaria (Actinopodea: Polycystina). Micropaleontology 36: 379-387.

Swanberg NR, Harbison GR (1980) The ecology of Collozoum longiforme, sp. nov., a new colonial radiolarian from the equatorial Atlantic Ocean. Deep-Sea Res Part A, 27: 715-731.

Takahashi K (1991) Radiolaria: Flux, ecology, and taxonomy in the Pacific and Atlantic. Ocean Biocoenosis Ser 3: 1-301.

Takahashi O, Yuasa T, Honda D, Mayama S (2004) Molecular phylogeny of solitary shell-bearing Polycystinea (Radiolaria). Rev Micropaléontol 47: 111-118.

Tan ZY (1998) Order Acantharia, Order Spumellaria. In: Fauna Sinica, Phylum Protozoa (eds Editorial Committee of Fauna Sinica, Academia Sinica). Science Publishing, Beijing, pp. 1-315. (in Chinese)

Tchang TR, Tan ZY (1964) Studies on the Radiolaria of the East China Sea. I. Acantharia. Stud Mar Sin 6: 33-78. (in Chinese with English abstract)

Yuasa T, Dolven JK, Bjørklund KR, Mayama S, Takahashi O (2009) Molecular phylogenetic position of Hexacontium pachydermum Jørgensen (Radiolaria). Mar Micropaleontol 73: 129-134.

Yuasa T, Takahashi O, Dolven JK, Mayama S, Matsuoka A, Honda D, Bjørklund KR (2006) Phylogenetic position of the small solitary phaeodarians (Radiolaria) based on 18S rDNA sequences by single cell PCR analysis. Mar Micropaleontol 59: 104-114.

Yuasa T, Takahashi O, Honda D, Mayama S (2005) Phylogenetic analyses of the polycystine Radiolaria based on the 18s rDNA sequences of the Spumellarida and the Nassellarida. Euro J Protistol 41: 287-298. 